\title{
The Way of Usage and Location in a Big City Agglomeration as Impact Factors of the Nurseries Indoor Air Quality
}

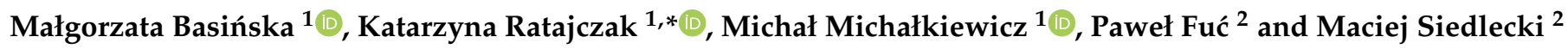 \\ 1 Institute of Environmental Engineering and Building Installations, Poznan University of Technology, \\ 60695 Poznan, Poland; malgorzata.basinska@put.poznan.pl (M.B.); \\ michal.michalkiewicz@put.poznan.pl (M.M.) \\ 2 Institute of Combustion Engines and Powertrains, Poznan University of Technology, 60695 Poznan, Poland; \\ pawel.fuc@put.poznan.pl (P.F.); maciej.siedlecki@put.poznan.pl (M.S.) \\ * Correspondence: katarzyna.m.ratajczak@put.poznan.pl
}

Citation: Basińska, M.; Ratajczak, K.; Michałkiewicz, M.; Fuć, P.; Siedlecki, M. The Way of Usage and Location in a Big City Agglomeration as Impact Factors of the Nurseries Indoor Air Quality. Energies 2021, 14, 7534. https://doi.org/10.3390/en14227534

Academic Editor: Magdalena

Hajdukiewicz

Received: 8 October 2021

Accepted: 5 November 2021

Published: 11 November 2021

Publisher's Note: MDPI stays neutral with regard to jurisdictional claims in published maps and institutional affiliations.

Copyright: (c) 2021 by the authors. Licensee MDPI, Basel, Switzerland. This article is an open access article distributed under the terms and conditions of the Creative Commons Attribution (CC BY) license (https:/ / creativecommons.org/licenses/by/ $4.0 /)$.

\begin{abstract}
The quality of outdoor air in many places, especially in urbanized areas, is bad; therefore, a series of studies aimed at assessing the impact of outdoor air parameters on indoor air quality was conducted. Four nurseries (three buildings) located in different parts of Poznań, Poland were selected as research sites. During the research period, the concentrations of $\mathrm{CO}_{2}, \mathrm{PM} 2.5$, and PM10 inside and outside the buildings over time were analyzed. Measurements outside the buildings were supplemented with an analysis of traffic near nurseries and an assessment of pollutant emissions from vehicles of various categories. Measurements were conducted during the COVID-19 pandemic in a weekly series during winter (December)—(W), spring (April)—(S), and at the end of spring (June) - (LS). Testing and analyses indicated poor indoor air quality in three out of four nurseries. To ensure indoor air quality at the proper level, it is necessary to supply rooms with outside air. Ventilating rooms by airing, when the outside air is polluted, reduces the $\mathrm{CO}_{2}$ concentration but worsens the indoor air quality in terms of particulate matter (PM). Seasonality in the concentration of particulate matter in outdoor air and its connection with the outside air temperature was noticed. No relationship between traffic and the values of $\mathrm{PM} 10$ and $\mathrm{CO}_{2}$ concentrations inside nurseries was observed.
\end{abstract}

Keywords: indoor air quality; nursery; outdoor air quality; $\mathrm{CO}_{2} ; \mathrm{PM} 10 ; \mathrm{IAQ}$; traffic

\section{Introduction}

\subsection{Outdoor Air Quality}

The impact of outdoor air quality (OAQ) on indoor air quality (IAQ) has been discussed in research for many years (from 1982 and earlier) [1]. Although the subject is well known, many problems related to the combination of OAQ and IAQ remain unsolved and have been noted by numerous studies [2-4]. The main pollutants of outdoor air that directly impact human health are, among others, particulate matter PM of various fractions and selected gaseous pollutants. When assessing outside air quality requirements, the EU Directive may be followed-the annual average PM2.5 concentration below $25 \mu \mathrm{g} / \mathrm{m}^{3}$ and the concentration of PM10 on a daily average below $50 \mu \mathrm{g} / \mathrm{m}^{3}$ [5]. These levels coincide with WHO interim target 2 [6].

Air quality may vary within a city and results from the types of heat sources used. The major component of some pollutants can be transported to the city from the surrounding region rather than emitted or produced locally [7]. The more greenery in the area and the more buildings connected to district heating, the better the outdoor air quality in such locations will be [8]. At the same time, in locations where coal is used to heat the buildings (in districts with single-family housing), more pollutants are emitted. During winter, if the outdoor PM concentration exceeds that of the non-heating season, then pollution comes 
from emissions due to fuel combustion. In the case when the similar values in each seasons are recorded, we can suggest that transport and industry may be the dominant factors [9].

The second cause of outdoor air pollution in urban areas is road transport. Vehicle exhausts primarily emit particles (dust) during transient processes such as starting and acceleration procedures. Additionally, in road congestion, many particles form due to underheating of the exhaust gas treatment systems [10]. Despite the newer European emission standards for toxic components introduced in European countries that reduce not only laboratory but also actual emission levels of toxic compounds, many cars in poor technical condition still remain on Polish roads.

\subsection{Indoor Air Quality (IAQ) vs. Outdoor Air Quality (OAQ)}

Indoor air quality is most often determined by indicators concerning the concentration of carbon dioxide, the concentration of volatile organic compounds whose emission sources are internal (people and interior furnishings), microbiological indicators (the number of bacteria and fungi) whose sources are internal and external, as well as by particulate matter concentration [11]. The most common sources of PM are external. Indoor air quality is thus partly due to the presence of people and partly due to the inflow of fresh air into the rooms.

Outdoor air is introduced into buildings to ensure proper hygienic conditions. Outdoor air, with a $\mathrm{CO}_{2}$ concentration of $\sim 400-450 \mathrm{ppm}$, replaces indoor air with higher $\mathrm{CO}_{2}$ concentrations due to respiration and combustion processes, e.g., gas cookers, stoves, fireplaces. For very good air quality, $\mathrm{CO}_{2}$ should not exceed $1000 \mathrm{ppm}$; the acceptable level is $\sim 1500 \mathrm{ppm}$ [12], and concentrations above $2000 \mathrm{ppm}$ constitute bad air quality [13].

In existing residential and non-residential buildings, outdoor air comes from natural ventilation where external air is supplied through window ventilators, special air supply grilles, unsealed windows, and opening the windows. Although such methods of air exchange are relatively easy to operate, especially opening windows, it results in the introduction of outside air without purification. If the outside air has poor quality, e.g., high PM concentrations, the situation inside the rooms will also be bad. At the same time, opening the windows when the outside temperature is cold may cause local discomfort. The situation is similar in warm climates during the summer months. High outside temperatures cause the inside temperatures to rise when opening the windows. A properly configured heating and cooling system may be a solution to the local discomfort caused by the supply of cold or hot air through airing, i.e., in the form of panels [14,15]; however, such a system does not remove particulate matter from the air.

Since most buildings do not have a mechanical ventilation system, many recommendations, including those relating to protection against the spread of viruses during a pandemic (including SARS-CoV-2), involve the use of intensive airing of rooms to ensure proper air quality.

\subsection{Research Goal}

The outdoor air in Poland, especially in urban areas, is polluted with the particulate matter. It may be associated with the building location. Therefore, it was decided to conduct a series of tests aimed at assessing the impact of outdoor air parameters on indoor air quality. A literature review and evaluation of publications describing the quality of air in schools, kindergartens, and nurseries (institutions intended for children under the age of 3), publications on nurseries comprised only $\sim 6 \%$ of publications.

Changes in $\mathrm{CO}_{2}, \mathrm{PM} 2.5$, and PM10 concentrations inside the rooms used by young children and of the outside air were analyzed. Measurements outside buildings were supplemented with measurements detailing the type, number, length, speed, and direction of movement of vehicles in the vicinity of these buildings. Additionally, using the rooms in the scope of supplying external air for hygienic purposes and its impact on indoor air quality indicators were assessed.

The main objective of the research was to assess the air quality in the rooms intended for the stay of young children during the hygiene recommendations related to the spread 
of COVID-19. In addition to the analysis of carbon dioxide concentration, the concentration of particulate matter pollutants on which bacteria and viruses can be carried was selected for the IAQ assessment. The conducted research was aimed at checking whether the recommended intensive airing of rooms during a pandemic is a good way to ensure adequate air quality. Answers were sought to the following questions:

1. Can proper indoor air quality be ensured by airing the rooms?

2. Is there a correlation between indoor and outdoor PM concentration and is it seasonal?

3. Is there a correlation between seasonal traffic and indoor air quality?

\section{Materials and Methods}

\subsection{Characteristics of the Analyzed Research Objects}

There are 116 institutions dedicated to the care of children up to 3 years of age in Poznań (population $~ 540,000$ ). Every fifth child of this age attends a nursery-the number of available places is 4900 .

IAQ tests were conducted in three existing buildings (four groups of children) in which rooms are ventilated naturally (by airing). In three of the buildings located in a different part of Poznan, rooms with one age group of children were selected for analysis, and one had two groups of children. In buildings B1\&B2 and B4, there were two rooms for each group of children - one used as a playroom, and the other separate room for sleeping. In the nursery marked as B3, children have one room where they spent the whole day playing or resting during an after-lunch nap. The characteristics of the research sites are presented in Table 1, and their location is shown in Figure 1.

Table 1. Characteristics of the analyzed research sites.

\begin{tabular}{|c|c|c|c|c|c|}
\hline \multirow{2}{*}{$\begin{array}{l}\text { Symbol } \\
\text { Nursery Symbol }\end{array}$} & & \multicolumn{2}{|c|}{ Buildings B1 \& B2 } & \multirow{2}{*}{$\begin{array}{c}\text { Building B3 } \\
\text { B3 }\end{array}$} & \multirow{2}{*}{$\begin{array}{c}\text { Building B4 } \\
\text { B4 }\end{array}$} \\
\hline & & B1 & B2 & & \\
\hline \multirow{4}{*}{ 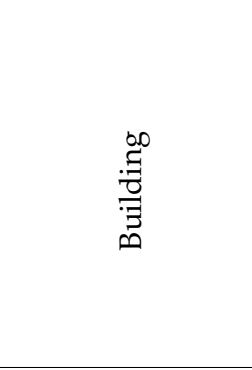 } & Type of building & \multicolumn{2}{|c|}{ adaptation of a semi-detached building } & $\begin{array}{l}\text { adaptation of } \\
\text { selected rooms in a } \\
\text { shopping area }\end{array}$ & $\begin{array}{l}\text { building designed } \\
\text { as a nursery }\end{array}$ \\
\hline & Location & \multicolumn{2}{|c|}{ district of single-family houses } & \multicolumn{2}{|c|}{ multi-family buildings } \\
\hline & $\begin{array}{l}\text { Distance from a } \\
\text { heavy traffic street }\end{array}$ & \multicolumn{2}{|c|}{$\begin{array}{l}100 \mathrm{~m} \text { from a busy street, numerous } \\
\text { separate buildings, } 9 \mathrm{~m} \text { from the } \\
\text { residential road }\end{array}$} & $\begin{array}{l}100 \mathrm{~m} \text { from the } \\
\text { main road }\end{array}$ & $\begin{array}{l}132 \mathrm{~m} \text { from the } \\
\text { main road, by a } \\
\text { residential road }\end{array}$ \\
\hline & Windows location & \multicolumn{2}{|l|}{ garden } & parking lot & park \\
\hline \multirow{3}{*}{ 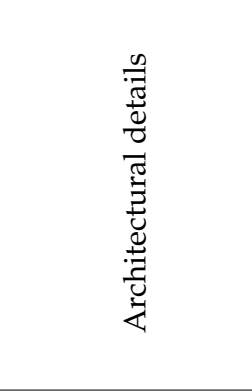 } & $\begin{array}{l}\text { Number of rooms } \\
\text { dedicated for each } \\
\text { group }\end{array}$ & 2 & 2 & 1 & 2 \\
\hline & $\begin{array}{l}\text { Playroom: } \\
\text { area }\left(\mathrm{m}^{2}\right) \\
\text { volume }\left(\mathrm{m}^{3}\right)\end{array}$ & $\begin{array}{l}\text { B1.1 } \\
41.0 \\
90.3\end{array}$ & $\begin{array}{l}\text { B2.1 } \\
62.1 \\
176.8\end{array}$ & \multirow{2}{*}{$\begin{array}{l}\text { One room B3 } \\
38.9 \\
51.7\end{array}$} & $\begin{array}{l}\text { B4.1 } \\
60.9 \\
199.8\end{array}$ \\
\hline & $\begin{array}{l}\text { Sleeping room: } \\
\text { area }\left(\mathrm{m}^{2}\right) \\
\text { volume }\left(\mathrm{m}^{3}\right)\end{array}$ & $\begin{array}{l}\text { B1.2 } \\
21.2 \\
55.0\end{array}$ & $\begin{array}{l}\text { B2.2 } \\
15.6 \\
49.1\end{array}$ & & $\begin{array}{l}\text { B } 4.2 \\
62.6 \\
205.3\end{array}$ \\
\hline \multirow{4}{*}{ 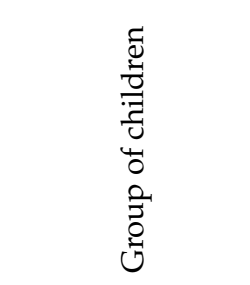 } & $\begin{array}{l}\text { Number of } \\
\text { children }\end{array}$ & 13 & 20 & 16 & 32 \\
\hline & Number of sitters & 2 & 2 & 3 & 3 \\
\hline & Age & $1-1.5$ & $1.5-2.5$ & 2 & $1.5-2$ \\
\hline & $\begin{array}{l}\text { Average } \\
\text { attendance }\end{array}$ & $66 \%$ & $68 \%$ & $90 \%$ & $76 \%$ \\
\hline
\end{tabular}




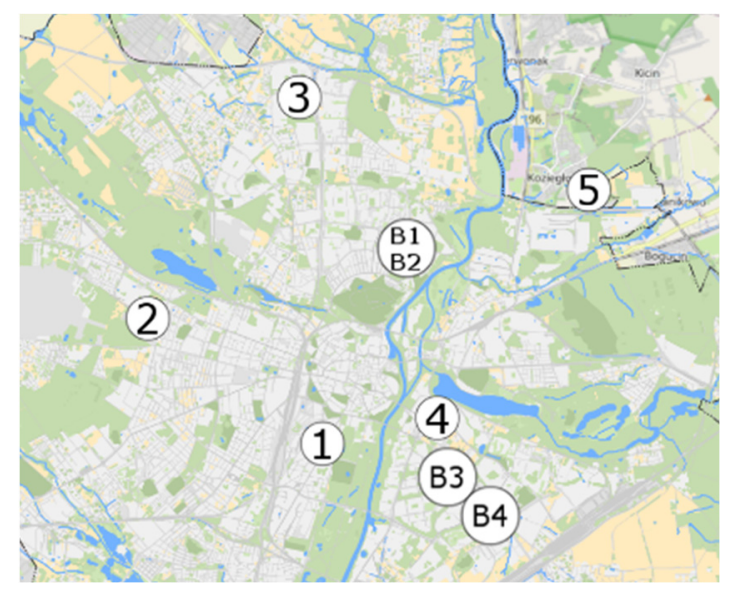

Figure 1. Map of Poznań [Source: Google Maps] with research sites (B1-B4) and measuring stations for outdoor air parameters of Regional Inspectorate for Environmental Protection (WIOS) (1-5).

The measurement data available from five city stations were used to assess the citywide OAQ [16]. The location of the measuring stations is shown in Figure 1, marking individual stations with Arabic numbers 1-5. Our measurements were supplemented by data from the monitoring stations of WIOS. Monitoring stations measured the following parameters of outdoor air quality: $\mathrm{PM} 10, \mathrm{PM} 2.5, \mathrm{NO}_{2}, \mathrm{NOx}, \mathrm{NO}, \mathrm{SO}_{2}, \mathrm{CO}$ and $\mathrm{C}_{6} \mathrm{H}_{6}$. In our research, we used information about particulate matter contaminations.

\subsection{Characteristics of the Analyzed Building Surroundings}

Poznan is one of the most crowded cities in Poland. Its administrative area is $262 \mathrm{~km}^{2}$, which results in a population density of 2061 people $/ \mathrm{km}^{2}$. For the entire country, the average population density is 122 people $/ \mathrm{km}^{2}$, which is approximately 17 times lower than for Poznań city. The impact of external air pollution due to the effects of pollutants emitted by cars of various types and ages is increasing due to the increase in the number of cars per 1000 inhabitants in Poland (in 1990, there were 138 passenger cars per 1000 inhabitants; this number increased to 617 in 2020). The average vehicle age in Poland is 14 years, higher than the European Union average (11.5 years). The average vehicle was homologated according to the Euro 4 standard, the limits of which were higher than the current Euro 6 for each measured compound, and there was a smaller number of limited compounds (especially for PM and PN). Research of scientific units around the world, including [17], proved that with the next new type approval standards, actual emissions also decreased. The degree of pollutant reduction, however, is lower than that resulting from limit reductions.

The nursery facilities analyzed are located in two communication areas of Poznan. Building B1\&B2 is located in the northern part of the city, approx. $100 \mathrm{~m}$ from a four-lane road with a tram line, in the center of a single-family housing area. Buildings B3 and B4, in the eastern part of the city, are located approximately $100 \mathrm{~m}$ from the main and transit four-lane road with tram and bus lines in the middle of a multi-family building area.

\subsection{Measurement Period}

Measurements were conducted during the COVID-19 pandemic; therefore, there were some restrictions regarding the installation of measuring devices. Therefore, the measurements were taken weekly in various locations and depended on facility availability. Measurements were conducted weekly during winter (December)—(W), spring (April) (S), and at the end of spring (June)-(LS).

Due to the presence of children in different rooms during the day, the days period were divided into three parts:

- $\quad$ Morning time (MT), playtime in the playroom;

- $\quad$ Nap time (NT) in a dedicated sleeping room;

- Afternoon time (AT), playtime in the playroom. 
Table 2 shows the measurement dates and measurement periods.

Table 2. Measurement periods for the four research groups.

\begin{tabular}{|c|c|c|c|c|}
\hline Nursery (Research Group) & B1 & B2 & B3 & B4 \\
\hline \multicolumn{5}{|c|}{ Indoor and outdoor air quality assessment } \\
\hline Winter time $(\mathrm{W})$ & \multicolumn{4}{|c|}{ 02-16 December 2020} \\
\hline Spring time (S) & \multicolumn{2}{|c|}{ 19-23 April 2021} & - & - \\
\hline Late spring time (LS) & \multicolumn{2}{|c|}{ 07-11 June 2021} & - & - \\
\hline Morning time (MT) & 8:00-11:00 & 8:00-11:00 & 8:00-16:00 & 8:00-11:30 \\
\hline Nap time (NT) & 11:00-13:00 & 11:00-13:00 & & 11:30-13:30 \\
\hline Afternoon time (AT) & 13:00-15:00 & 13:00-15:00 & $\begin{array}{l}\text { Nap time in the same } \\
\text { room }(11: 30-14: 00)\end{array}$ & 13:30-16:00 \\
\hline \multicolumn{5}{|l|}{ Traffic assessment } \\
\hline Winter time $(\mathrm{W})$ & \multicolumn{2}{|c|}{1 December 2020} & 4 December 2020 & 8 December 2020 \\
\hline Late spring time (LS) & \multicolumn{2}{|c|}{7 June 2021} & - & - \\
\hline
\end{tabular}

\subsection{Indoor and Outdoor Air Quality Assessments}

\subsubsection{Measuring Devices}

For air quality measurements, measuring equipment was used for continuous monitoring of the following air parameters: particulate matter concentration PM2.5, PM10 $\left(\mu \mathrm{g} / \mathrm{m}^{3}\right)$, temperature $\left({ }^{\circ} \mathrm{C}\right)$, relative humidity $(\%)$, in indoor and outdoor air, and the indoor concentration of carbon dioxide (ppm). Measurements were made with NEMo Outdoor and NEMo XT mini devices by Ethera (France). The devices were calibrated. The accuracies and measuring ranges of the devices used are listed in Table 3.

Table 3. Measuring device characteristics used for IAQ and OAQ measurements.

\begin{tabular}{|c|c|c|}
\hline Parameter & & $\begin{array}{l}\text { NEMo XT Mini } \\
\text { NEMo Outdoor }\end{array}$ \\
\hline \multirow{4}{*}{ Carbon dioxide } & Detection method & Non-dispersive infrared spectrometry \\
\hline & Measuring range & $0-5000 \mathrm{ppm}$ \\
\hline & Resolution & $1 \mathrm{ppm}$ \\
\hline & Accuracy & $\pm 50 \mathrm{ppm}$ \\
\hline \multirow{4}{*}{ Temperature } & Detection method & $\begin{array}{c}\text { CMOS (Complementary } \\
\text { Metal-Oxide-Semiconductor) }\end{array}$ \\
\hline & Measuring range & $(-55)-(+125){ }^{\circ} \mathrm{C}$ \\
\hline & Resolution & $0.08{ }^{\circ} \mathrm{C}$ \\
\hline & Accuracy & $\pm 0.5^{\circ} \mathrm{C}$ \\
\hline \multirow{4}{*}{ Relative humidity } & Detection method & Capacitive \\
\hline & Measuring range & $0-95 \%$ \\
\hline & Resolution & $0.08 \%$ \\
\hline & Accuracy & $\pm 3 \%$ \\
\hline \multirow{4}{*}{ PM2.5/PM10 } & Detection method & Laser-based light scattering \\
\hline & Measuring range & $0-1000 \mu \mathrm{g} / \mathrm{m}^{3}$ \\
\hline & Resolution & $1 \mu \mathrm{g} / \mathrm{m}^{3}$ \\
\hline & Accuracy & $\pm 5 \%$ \\
\hline
\end{tabular}


Devices for monitoring opening windows were also used, which registered the opening of a window in the zero-one system, an open window (1), and a closed window (0).

\subsubsection{Methodology}

Air quality was assessed in terms of $\mathrm{CO}_{2}$ concentration and particulate matter. The average concentrations of these selected indicators were determined during the children's stay in the nursery, accounting for the time of their stay in the playroom and sleeping room. The assumed evaluation criteria for good IAQ are as follows:

- The average concentration of $\mathrm{CO}_{2}$ below1200 ppm, and the maximum concentration below 1500 ppm;

- The maximum concentration of PM10 below $50 \mu \mathrm{g} / \mathrm{m}^{3}$;

- The maximum concentration of PM2.5 below $25 \mu \mathrm{g} / \mathrm{m}^{3}$.

The ratio of the indoor and outdoor concentration, $\mathrm{I} / \mathrm{O}$, of the given parameter was determined to assess the impact of outdoor air parameters on indoor air parameters.

\subsection{Traffic Assessment}

\subsubsection{Measuring Devices}

An apparatus measuring traffic assessed and analyzed the traffic volume in selected places near analyzed buildings. Measurements were made using a TOPO device, brand VITRONIC Machine Vision (Poland), which measured:

- $\quad$ Speed of the passing vehicle;

- The direction of vehicle movement;

- Length and number of axles of passing vehicles;

- Belonging to one of the 10 vehicle groups.

The analyzed vehicle groups included bicycles, motorcycles, compact vehicles, passenger vehicles, delivery vehicles, delivery vehicles with a trailer, heavy vehicles, heavy vehicles with a trailer, oversized vehicles, and buses.

The technical characteristics of the applied TOPO apparatus are shown in Table 4 . The number and classification of vehicles were measured in $10 \mathrm{~min}$ cycles and time-correlated with air quality measurements.

Table 4. Technical characteristics of the TOPO apparatus.

\begin{tabular}{ll}
\hline Dimensions & $41 \times 35 \times 18 \mathrm{~cm}$ \\
\hline Signal frequency & 24 to $24.25 \mathrm{GHz}$ \\
\hline Working temperature & $-30{ }^{\circ} \mathrm{C}$ to $50{ }^{\circ} \mathrm{C}$ \\
\hline Battery life & Up to 7 days \\
\hline Measurement memory & Up to 500,000 vehicles \\
\hline Type of communication & Bluetooth, GPRS with FTP \\
\hline
\end{tabular}

\subsubsection{Methodology}

During this research, only six vehicle categories (Passenger Cars (PC), Heavy Duty Vehicles (HDV/Bus) and long Heavy Duty Vehicles (long HDV), Motorcycles, Minivan/SUV (Van) and Undefined vehicles (Undefined)) were used due to previously obtained results of actual emissions from small passenger cars, passenger cars, two-wheelers, vans, heavy vehicles, and heavy vehicles with a hitch while driving in the Poznań agglomeration [16,18-22]. The analyses were performed over 10 min intervals, vehicles, and emissions were summed up over $10 \mathrm{~min}$ periods of traffic intensity according to the sampling frequency of the air quality analyzers placed inside and outside the nurseries. 
Those results were multiplied by average concentrations from the exhaust systems previously measured in real operating conditions from the research carried out with the PEMS apparatus in the Poznań agglomeration (Table 5).

Table 5. Per-second emission values used in the calculation of pollutants emitted from vehicles [18-22].

\begin{tabular}{lcccccc}
\hline $\begin{array}{l}\text { Vehicle Group/Assumed } \\
\text { Emission Intensity }\end{array}$ & $\begin{array}{c}\text { Passenger } \\
\text { Vehicles }\end{array}$ & Motorcycle & $\begin{array}{c}\text { Delivery } \\
\text { Vehicles }\end{array}$ & $\begin{array}{c}\text { Buses and } \\
\text { Trucks }\end{array}$ & $\begin{array}{c}\text { Heavy Vehicle } \\
\text { Assemblies }\end{array}$ & $\begin{array}{c}\text { Unclassified } \\
\text { Vehicles }\end{array}$ \\
\hline $\mathrm{CO}_{2}(\mathrm{mg} / \mathrm{s})$ & 2296 & 988 & 2684 & 5824 & 6930 & - \\
\hline $\mathrm{PM}(\mathrm{ng} / \mathrm{s})$ & 3.4 & 1.1 & 4.8 & 24.7 & 31.3 & - \\
\hline
\end{tabular}

The values listed in Table 5 are average values for spark-ignition and compressionignition engines in passenger vehicles.

For delivery vehicles, buses, trucks, and vehicle combinations, data from compressionignition engines were used due to the marginal share of gas and petrol engines in the market. When the equipment detects non-classified vehicles, their number was not included in the analysis. The emission intensity was determined as the averaged mass of a given compound emitted from the exhaust system for one second.

\section{Results}

\subsection{Assessment of the Outdoor Air Quality}

Based on the comparative analysis of the PM10 concentration in Poznan and depending on the location of the Poznan measuring stations [16], comparable values of the air pollution degree with PM are shown. Therefore, for further analyses for all nursery locations, outdoor air quality measurement data taken at building B1\&B2 were used (our research). Figure 2 shows the variability in time of the pollutants, a comparison of the PM2.5 and PM10 concentrations over selected weekly periods of the year: winter time (W), spring time (S), and the turn of spring and summer (LS) for building B1 \& B2. No data in the part of the diagram in Figure 2a was caused by a $4 \mathrm{~h}$ interruption in the power supply, which was caused by the recorder temporarily shutting down. Additionally, the graphs show the variability of the outdoor temperature and relative humidity. The mean values from the measurement periods are presented in Table 6.

Table 6. Outdoor air parameters at three time periods: average with standard deviation, maximum, and minimum values.

\begin{tabular}{|c|c|c|c|c|c|c|c|c|c|c|c|c|}
\hline \multirow[b]{2}{*}{ Period } & \multicolumn{4}{|c|}{ Average } & \multicolumn{4}{|c|}{ Maximum } & \multicolumn{4}{|c|}{ Minimum } \\
\hline & $\begin{array}{c}\mathrm{T} \\
\left({ }^{\circ} \mathrm{C}\right)\end{array}$ & $\begin{array}{l}\text { RH } \\
\text { (\%) }\end{array}$ & $\begin{array}{r}\text { PM2.5 } \\
\quad(\mu \mathrm{g}\end{array}$ & $\begin{array}{l}\text { PM10 } \\
\left.\text { m }^{3}\right)\end{array}$ & $\begin{array}{c}\mathrm{T} \\
\left({ }^{\circ} \mathrm{C}\right)\end{array}$ & $\begin{array}{l}\text { RH } \\
(\%)\end{array}$ & $\begin{array}{r}\text { PM2. } \\
\quad(\mu \xi\end{array}$ & PM10 & $\begin{array}{c}\mathrm{T} \\
\left({ }^{\circ} \mathrm{C}\right)\end{array}$ & $\begin{array}{l}\text { RH } \\
(\%)\end{array}$ & PM & $\begin{array}{l}\text { PM10 } \\
\text { m }^{3} \text { ) }\end{array}$ \\
\hline Winter $(\mathrm{W})$ & $3.2 \pm 2.7$ & $82 \pm 5$ & $74 \pm 29$ & $122 \pm 62$ & 13.5 & 93 & 171 & 446 & -1.8 & 64 & 25 & 25 \\
\hline Spring (S) & $13.4 \pm 5.6$ & $54 \pm 16$ & $13 \pm 9$ & $18 \pm 11$ & 28.0 & 85 & 65 & 80 & 4.3 & 17 & 3 & 4 \\
\hline Late spring (LS) & $22.7 \pm$ & $50 \pm 13$ & $4 \pm$ & $7 \pm 3$ & 35.0 & 75 & 14 & 19 & 15.8 & 21 & 1 & 2 \\
\hline
\end{tabular}

Based on our research and subsequent analyses, the outside air is characterized by changing parameters throughout the year; a seasonal nature of external air pollution with PM was observed. In December (W), high concentrations of PM10 and PM2.5 were recorded. In April (S), when the outside air temperature averaged $13.4{ }^{\circ} \mathrm{C}$, the PM concentrations were about 13 and $18 \mu \mathrm{g} / \mathrm{m}^{3}$. Maximum concentrations (values exceeding the limit values according to WHO, $65 \mu \mathrm{g} / \mathrm{m}^{3}$ and $80 \mu \mathrm{g} / \mathrm{m}^{3}$ ) were recorded for PM2.5 and PM10 in the winter when they reached $171 \mu \mathrm{g} / \mathrm{m}^{3}$ and $446 \mu \mathrm{g} / \mathrm{m}^{3}$. In June (LS), PM concentrations were below the values required by the WHO in terms of average and maximum values. Figure 3 shows the dependence of the concentrations of PM2.5 and PM10 and outside air temperature. As the outside air temperature increases, the concentration of PM2.5 and PM10 in the air decreases. These results confirm the seasonality of outdoor air pollution and its connection to outdoor air temperature. 
(a)

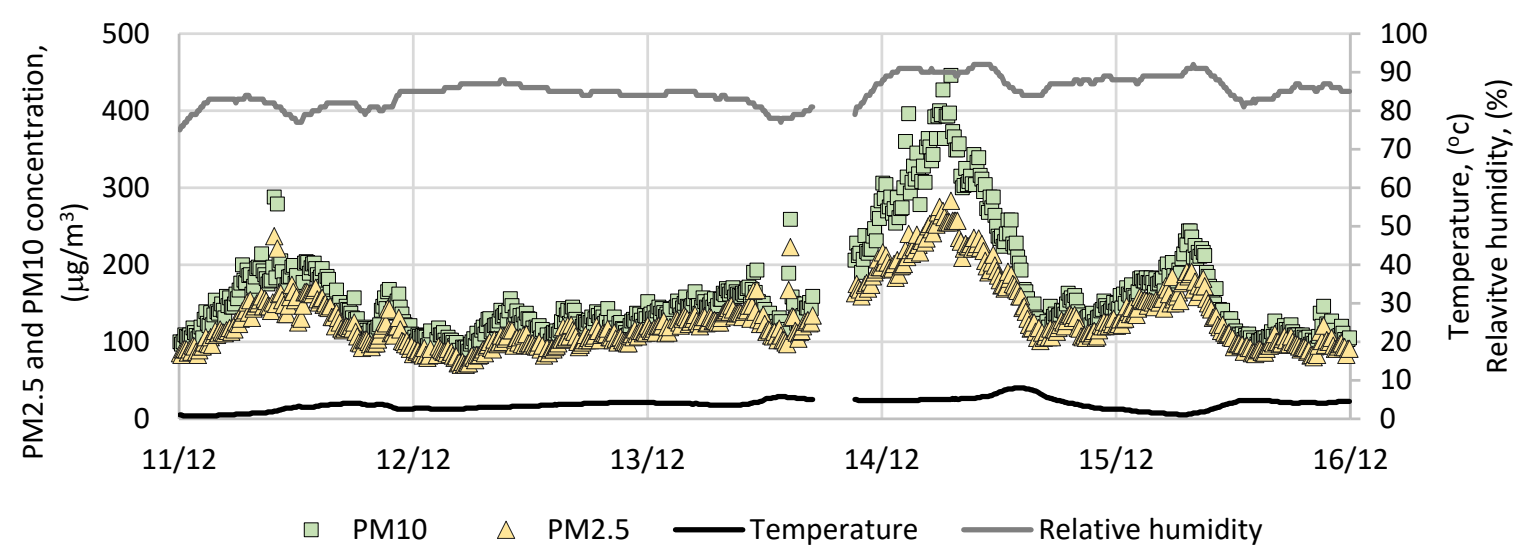

(b)

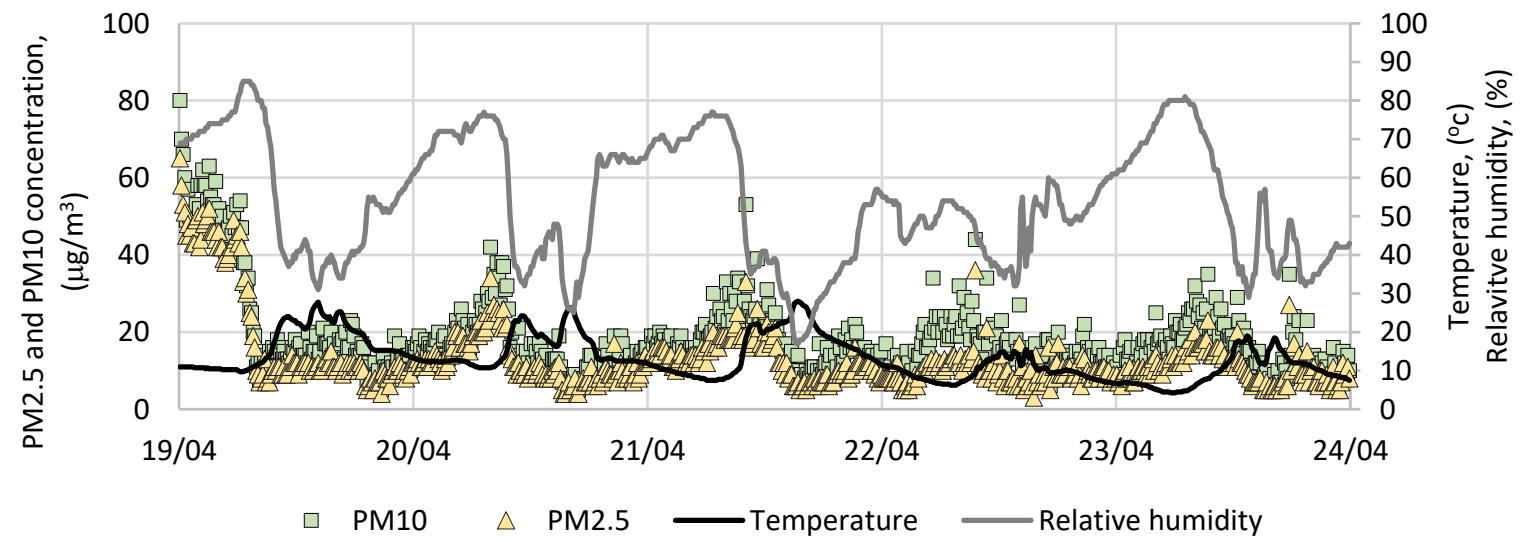

(c)

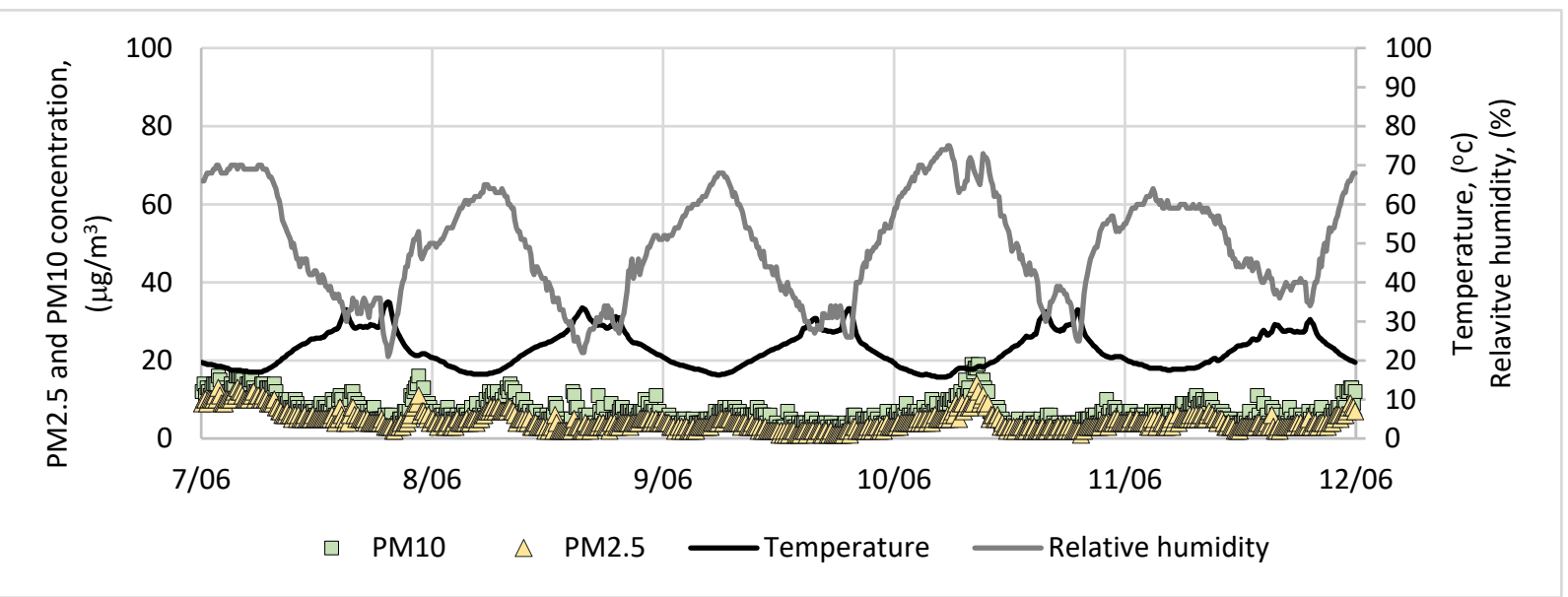

Figure 2. Particulate matter variability in three periods of the year: (a) winter (W) (11-16 December 2020), (b) spring (S) (19-23 April 2021), (c) late spring (LS) (07-11 June 2021). 
(a)

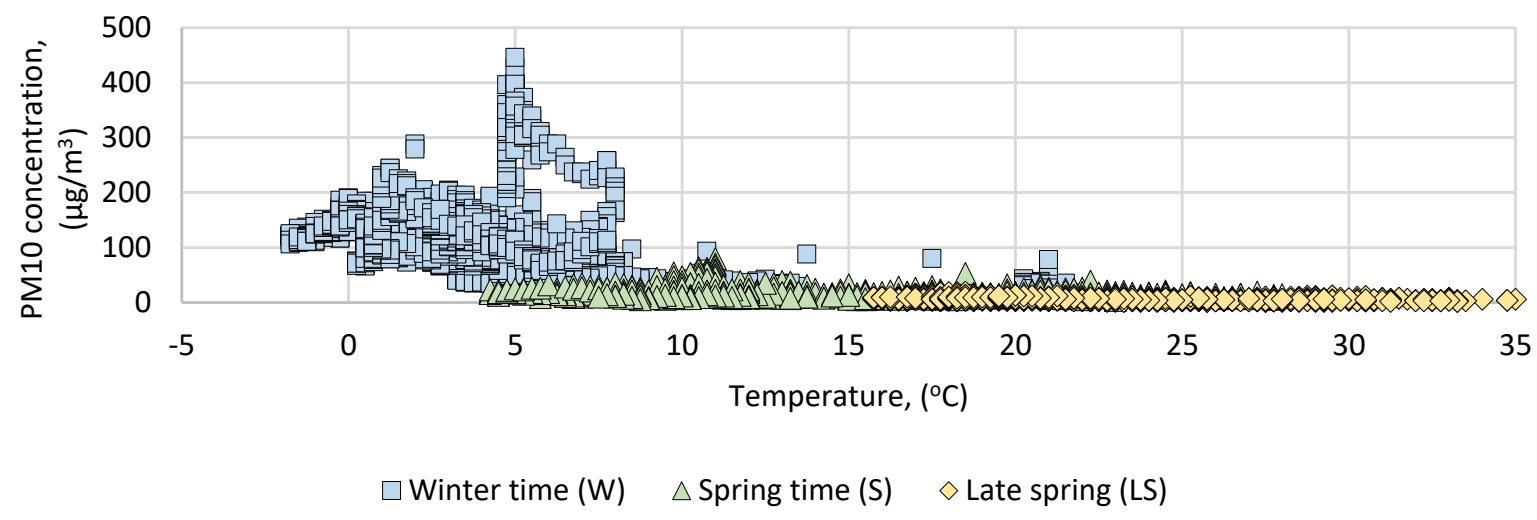

(b)

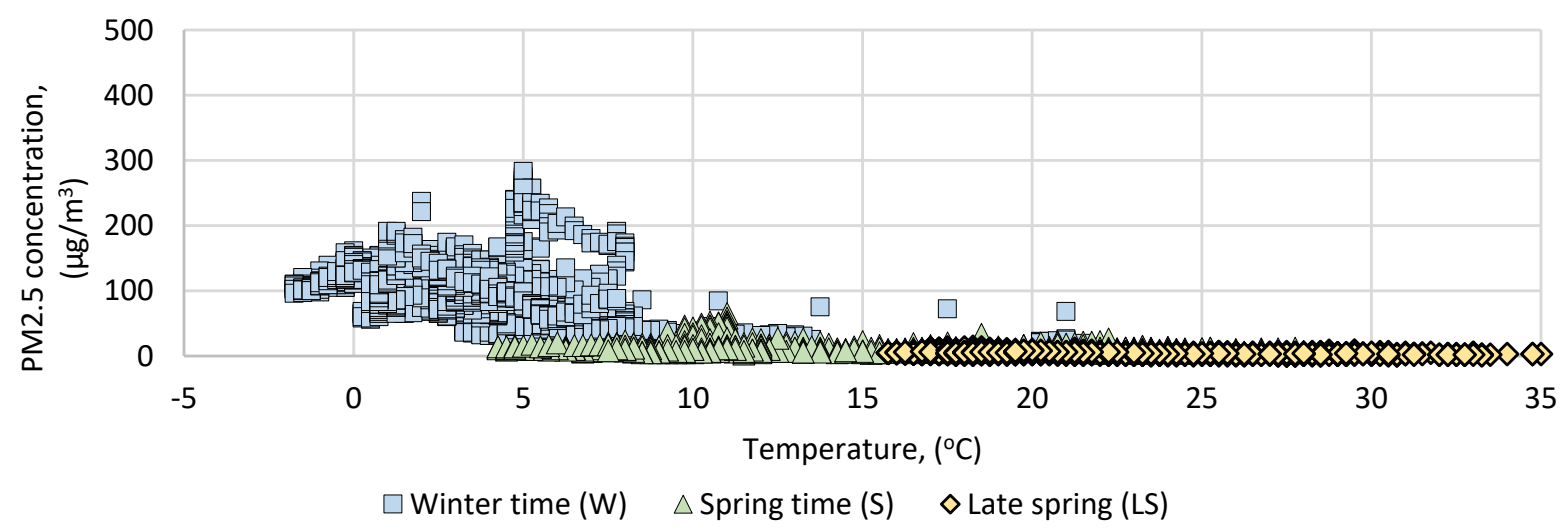

Figure 3. Concentrations of PM2.5 and PM10 in four measurement periods and the outside air temperature for (a) PM2.5, (b) PM10.

In terms of PM2.5 and PM10 concentration, there are large daily differences in the recorded values. Due to the seasonality of outdoor air parameters, analyses were performed in the winter (W), spring (S), and the late spring (LS) periods. The days selected for detailed analysis are characterized by the lowest or the highest concentration of dust particles in the outside air. Table 7 presents the average daily values of PM concentrations and the maximum values recorded for each day, as well as the average wind speed for three characteristic time periods from 8:00 to 16:00 (the period of children's stay in the nursery) influencing the spread of pollutants. The average daily PM10 concentration in the winter was $129 \mu \mathrm{g} / \mathrm{m}^{3}$ and ranged from 25 to $260 \mu \mathrm{g} / \mathrm{m}^{3}$; the PM2.5 average was $101 \mu \mathrm{g} / \mathrm{m}^{3}$ and ranged from 37 to $260 \mu \mathrm{g} / \mathrm{m}^{3}$.

The highest PM concentration values in winter were recorded on days when the wind speed was relatively low ( $<20 \mathrm{~km} / \mathrm{h}$, worst day-Monday, 14 December 2020). During the winter $(\mathrm{W})$, the outside air temperature was relatively constant and low (average $3.2 \pm 2.7^{\circ} \mathrm{C}$ ); therefore, wind ultimately determined PM concentration level and this agreed with previous literature results [23]. On the other hand, the best situation occurred on Monday, 7 December 2020 - the concentration of PM10 qualified the quality of the outside air as good. For PM2.5, good air quality was not achieved in the winter (average $<25 \mu \mathrm{g} / \mathrm{m}^{3}$ ). 
Table 7. The average and maximum concentrations of PM2.5 and PM10 in the outside air during the period when the children are in the nursery (8:00-16:00) along with the average wind speed.

\begin{tabular}{|c|c|c|c|c|c|c|c|c|c|c|c|c|c|}
\hline \multirow{2}{*}{\multicolumn{2}{|c|}{ Date/Period of Time }} & \multicolumn{2}{|c|}{ PM10 } & \multicolumn{2}{|c|}{ PM2.5 } & \multirow{3}{*}{$\begin{array}{l}\text { Wind } \\
\text { Speed }\end{array}$} & \multirow{3}{*}{\multicolumn{2}{|c|}{$\begin{array}{l}\text { Date/Period of } \\
\text { Time }\end{array}$}} & \multicolumn{2}{|c|}{ PM10 } & \multicolumn{2}{|c|}{ PM2.5 } & \multirow{3}{*}{$\begin{array}{l}\text { Wind } \\
\text { Speed }\end{array}$} \\
\hline & & \multirow{3}{*}{$\begin{array}{c}\text { Max } \\
186 \\
\end{array}$} & \multirow{2}{*}{$\frac{\text { Ave. }}{(\mu \mathrm{g} /}$} & \multirow{2}{*}{$\begin{array}{l}\text { Max } \\
3)\end{array}$} & \multirow[t]{2}{*}{ Ave. } & & & & \multirow[t]{2}{*}{ Max } & \multirow{2}{*}{$\frac{\text { Ave. }}{(\mu \mathrm{g} /}$} & \multirow{2}{*}{$\frac{\operatorname{Max}}{\left.m^{3}\right)}$} & \multirow[t]{2}{*}{ Ave. } & \\
\hline & & & & & & & & & & & & & \\
\hline \multirow{10}{*}{ 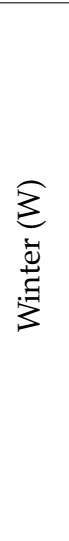 } & 2 December & & 166 & 186 & 154 & 16.0 & \multirow{5}{*}{ 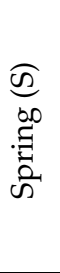 } & 19 April & 21 & 15 & 15 & 11 & 11.8 \\
\hline & 3 December & 189 & 153 & 189 & 154 & 18.8 & & 20 April & 38 & 17 & 27 & 13 & 10.8 \\
\hline & 4 December & 92 & 79 & 92 & 79 & 23.3 & & 21 April & 53 & 22 & 33 & 16 & 18.8 \\
\hline & 7 December & 45 & 37 & 45 & 40 & 29.8 & & 22 April & 44 & 18 & 36 & 10 & 24.3 \\
\hline & 8 December & 89 & 75 & 89 & 72 & 22.5 & & 23 April & 35 & 18 & 27 & 10 & 21.3 \\
\hline & 9 December & 108 & 91 & 108 & 89 & 20.5 & \multirow{5}{*}{ 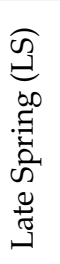 } & 7 June & 23 & 8 & 8 & 6 & 7.0 \\
\hline & 10 December & 124 & 96 & 124 & 100 & 14.3 & & 8 June & 22 & 9 & 8 & 4 & 10.5 \\
\hline & 11 December & 288 & 191 & 288 & 237 & 13.5 & & 9 June & 19 & 7 & 4 & 2 & 15.8 \\
\hline & 14 December & 343 & 260 & 343 & 235 & 12.3 & & 10 June & 30 & 10 & 14 & 5 & 8.5 \\
\hline & 15 December & 225 & 140 & 225 & 182 & 13.0 & & 11 June & 17 & 8 & 9 & 4 & 8.8 \\
\hline
\end{tabular}

In spring (S), there was one day (Wednesday, 21 April 2021) when the maximum concentration values of PM10 and PM2.5 exceeded the threshold limits, but the daily mean value was $<25 \mu \mathrm{g} / \mathrm{m}^{3}$. Maximum PM2.5 concentration levels were also exceeded on other days of that selected week, though the daily average for PM2.5 for the spring week was $12 \pm 2.5 \mu \mathrm{g} / \mathrm{m}^{3}$.

The concentrations of PM10 and PM2.5 were low in June, the end of spring (LS), and the maximum threshold value was not exceeded on any day. In the warmer period, the wind speed does not translate so much into particulate matter concentration, which may be related to lower dust emission from heat sources.

\subsection{Assessment of the Indoor Air Quality}

\subsubsection{Indoor Air Quality-Average over Time of Use}

For general IAQ assessment in individual nursery rooms, an indicator for assessing ventilation efficiency was used, described by the concentration of carbon dioxide. The analyses and the general assessments were conducted during times children spent in the rooms, (from 8:00 a.m. to 4:00 p.m.) for the three measurement periods described in Table 2. Additionally, Table 8 shows the concentrations of PM2.5 and PM10.

Observations based on the conducted measurements and analyses:

- $\quad$ For the winter period $(\mathrm{W})$

1. The requirement (below $1500 \mathrm{ppm}$ ) for the average level of $\mathrm{CO}_{2}$ concentration when children stayed at the facility was met in building B4. In nurseries B2 and $\mathrm{B} 3$, the situation in terms of $\mathrm{CO}_{2}$ concentration was bad, the average concentration exceeded $1500 \mathrm{ppm}$. It was even worse in nursery $\mathrm{B} 1$ where the average concentration exceeded $2000 \mathrm{ppm}$.

2. $\mathrm{CO}_{2}$ concentrations above $1500 \mathrm{ppm}$ for rooms in nurseries $\mathrm{B} 1$ and $\mathrm{B} 3$ occurred $70 \%$ of the time spent by children in the nursery.

3. PM10 concentrations remained below $50 \mu \mathrm{g} / \mathrm{m}^{3}$ in all of the nursery rooms. The lowest mean concentration of PM10 was recorded in nursery B1 $\left(17 \pm 6 \mu \mathrm{g} / \mathrm{m}^{3}\right)$, and the highest in nursery B4 $\left(22 \pm 9 \mu \mathrm{g} / \mathrm{m}^{3}\right)$.

4. There were occurrences of excess PM2.5 concentration levels $\left(>25 \mu \mathrm{g} / \mathrm{m}^{3}\right)$. The highest concentration was recorded on 14 December 2020 and the range was from $28-35 \mu \mathrm{g} / \mathrm{m}^{3}$. The fewest days with excessive PM2.5 concentrations during children's stay in the nursery occurred in nursery B1 (just two days), with an average concentration of PM2.5 $18 \pm 7 \mu \mathrm{g} / \mathrm{m}^{3}$. The highest number of excesses 
and highest average value in winter occurred in nurseries B2 and B4-three days with an average concentration of $20 \pm 9 \mu \mathrm{g} / \mathrm{m}^{3}$ and four days with an average concentration of $20 \pm 8 \mu \mathrm{g} / \mathrm{m}^{3}$.

5. In each of the nurseries, the best air quality in terms of PM concentration was recorded on 7 December 2020, and the worst on 14 December 2020, which were the days with the lowest and the highest PM concentration, respectively, in the outdoor air.

- For the late spring period (LS)

6. In nurseries B1\&B2, much better air quality parameters were registered relative to winter.

7. As in winter, the air quality was better in nursery B2 because rooms intended for children have a larger room space, so carbon dioxide emitted from breathing is diluted in a larger volume of internal air.

Table 8. Average carbon dioxide concentration $\mathrm{CO}_{2}$, concentrations of PM2.5 and PM10 during children's stay in the nursery on individual winter (W) and late spring (LS) days.

\begin{tabular}{|c|c|c|c|c|c|c|c|c|c|c|c|c|}
\hline \multirow{3}{*}{ Data } & \multicolumn{3}{|c|}{ B1 } & \multicolumn{3}{|c|}{ B2 } & \multicolumn{3}{|c|}{ B3 } & \multicolumn{3}{|c|}{ B4 } \\
\hline & $\mathrm{CO}_{2}$ & PM2.5 & PM10 & $\mathrm{CO}_{2}$ & PM2.5 & PM10 & $\mathrm{CO}_{2}$ & PM2.5 & PM10 & $\mathrm{CO}_{2}$ & PM2.5 & PM10 \\
\hline & (ppm) & \multicolumn{2}{|c|}{$\left(\mu \mathrm{g} / \mathrm{m}^{3}\right)$} & (ppm) & \multicolumn{2}{|c|}{$\left(\mu \mathrm{g} / \mathrm{m}^{3}\right)$} & (ppm) & \multicolumn{2}{|c|}{$\left(\mu \mathrm{g} / \mathrm{m}^{3}\right)$} & (ppm) & \multicolumn{2}{|c|}{$\left(\mu \mathrm{g} / \mathrm{m}^{3}\right)$} \\
\hline \multicolumn{13}{|c|}{ Winter Time $(W)$} \\
\hline 2 December & 1904 & 23 & 24 & 1414 & 31 & 33 & 1887 & 24 & 26 & 1039 & 30 & 31 \\
\hline 3 December & 1955 & 20 & 21 & 1578 & 23 & 25 & 1850 & 21 & 24 & 1136 & 24 & 26 \\
\hline 4 December & 2055 & 14 & 15 & - & - & - & 1671 & 19 & 21 & 867 & 23 & 24 \\
\hline 7 December & 2394 & 7 & 8 & 1633 & 8 & 9 & - & - & - & 1220 & 8 & 9 \\
\hline 8 December & 1950 & 11 & 12 & 1660 & 13 & 14 & - & - & - & 1352 & 13 & 14 \\
\hline 9 December & 1838 & 12 & 13 & - & - & - & - & - & - & 1317 & 15 & 16 \\
\hline 10 December & 1866 & 15 & 17 & 1645 & 17 & 19 & - & - & - & 1364 & 15 & 16 \\
\hline 11 December & 2030 & 27 & 30 & 1513 & 31 & 34 & 1809 & 30 & 35 & 1162 & 27 & 30 \\
\hline 14 December & 2299 & 28 & 31 & 1810 & 34 & 38 & 2021 & 35 & 38 & 1084 & 35 & 39 \\
\hline 15 December & 2186 & 22 & 23 & 1622 & 21 & 23 & 1710 & 23 & 25 & 1062 & 26 & 28 \\
\hline 16 December & 1719 & 14 & 14 & 1864 & 13 & 14 & 1922 & 13 & 14 & 1105 & 15 & 16 \\
\hline \multicolumn{13}{|c|}{ Late spring (LS) } \\
\hline 7 June & 1177 & 10 & 11 & 952 & 8 & 8 & - & - & - & - & - & - \\
\hline 8 June & 1116 & 6 & 7 & 845 & 5 & 5 & - & - & - & - & - & - \\
\hline 9 June & 1075 & 4 & 4 & 818 & 3 & 4 & - & - & - & - & - & - \\
\hline 10 June & 1186 & 6 & 7 & 945 & 6 & 6 & - & - & - & - & - & - \\
\hline 11 June & 1233 & 7 & 7 & 991 & 6 & 6 & - & - & - & - & - & - \\
\hline
\end{tabular}

3.2.2. Indoor Air Quality-The Impact of the Way of Use in Terms of Ventilation

One way to improve IAQ is airing the rooms and is effective when the outside air is clean (low PM concentration). At certain times, not during winter, it is cheap and easy to operate. However, if outdoor air pollution is high, this action may temporarily worsen indoor air quality. Therefore, to confirm the above thesis, the carbon dioxide concentration change and PM10 levels in playrooms of selected nurseries in different measurement periods were analyzed.

For B1, with the worst air quality, and B4, with the best indoor air quality, the course of $\mathrm{CO}_{2}$ and PM2.5 concentrations on winter days with the best (07 December 2020) and 
the worst (14 December 2020) outdoor air quality were analyzed. The results are shown in Figure $4 \mathrm{a}, \mathrm{b}$ for nurseries B1 and B4, respectively.

(a)
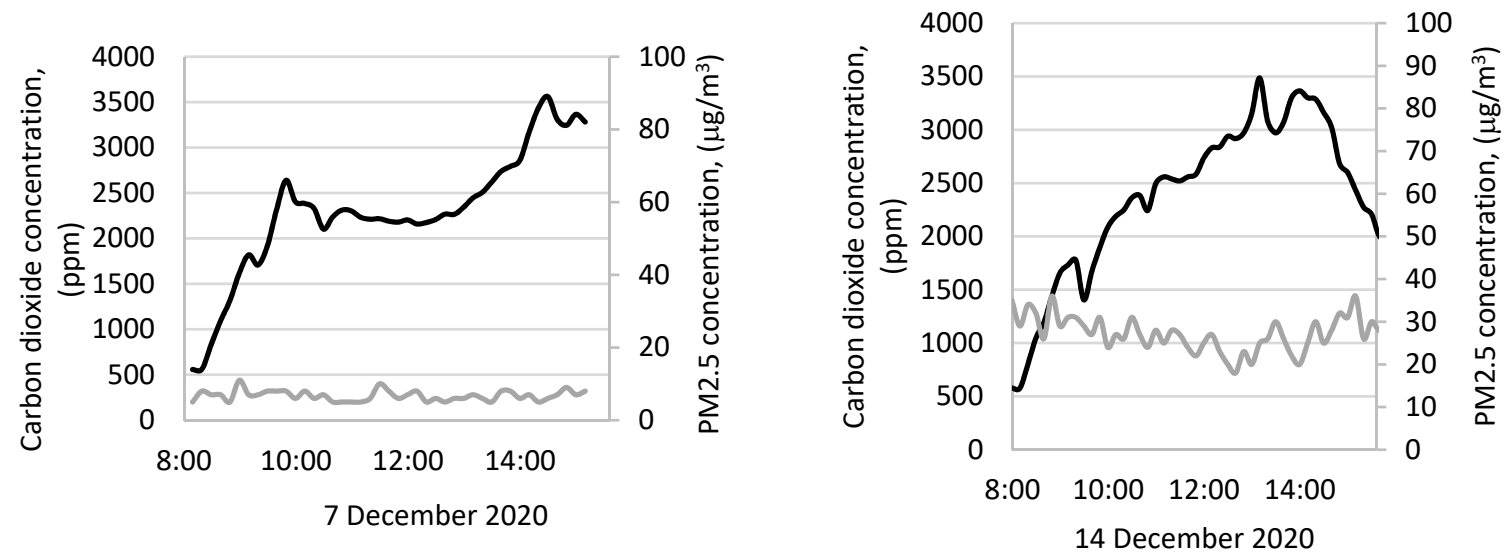

(b)
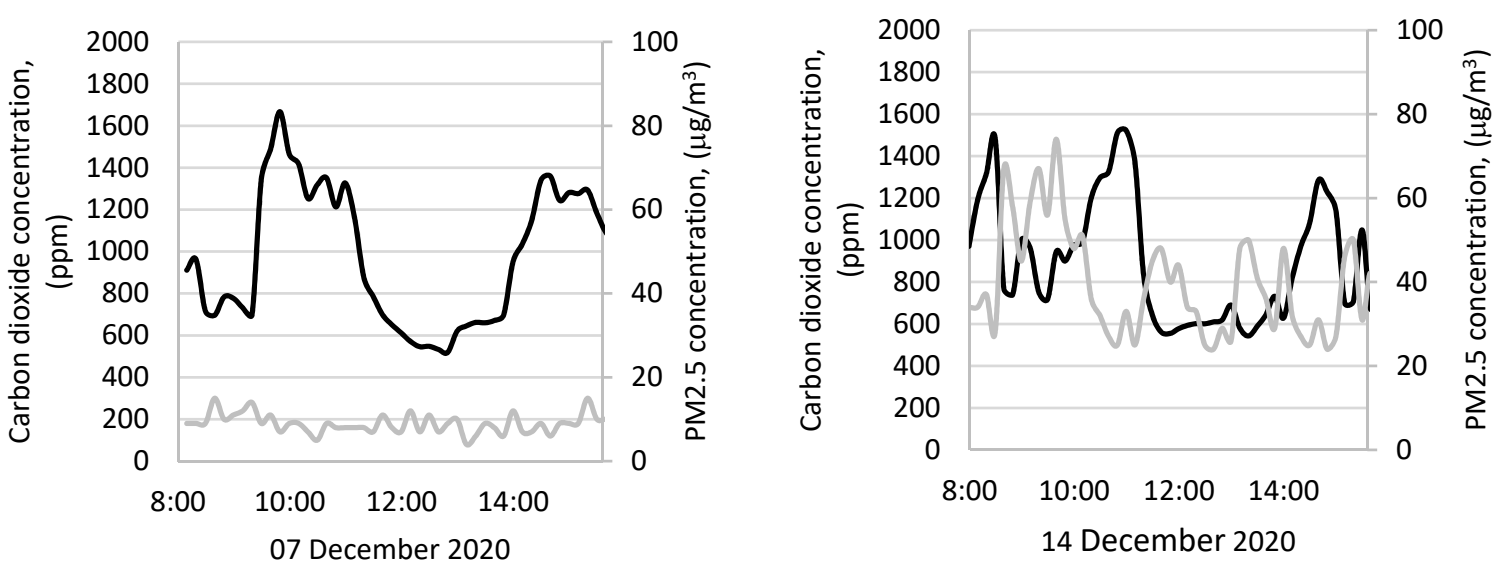

$-\mathrm{CO} 2-\mathrm{PM} 2.5$

Figure 4. Concentrations of $\mathrm{CO}_{2}$ and PM2.5 (every $10 \mathrm{~min}$ ) in the outdoor air during the day with the lowest (07 December 2020) and highest (14 December 2020) concentrations of PM2.5 in the nursery's playroom, (a) nursery B1, and (b) nursery B4.

In nursery B1, changes in carbon dioxide concentration had similar variabilities. The lowest concentration ( $\sim 500 \mathrm{ppm})$ was in the morning when the children were coming to the nursery due to the lack of occupation the previous night. Increases in $\mathrm{CO}_{2}$ concentration are caused by respiration from people in the room. In the middle of the day, children took a nap in another room and $\mathrm{CO}_{2}$ levels dropped. After the nap period, when children returned to the playroom, $\mathrm{CO}_{2}$ levels increased, though that increase was not as significant as in the morning, because some children were picked up after their naps. On 7 December, 10 children were present in the group, and on 14 December 2020, there were eight children present. On both days, $\mathrm{CO}_{2}$ levels reached maximum values of $3500 \mathrm{ppm}$. The average $\mathrm{CO}_{2}$ concentration in the playroom and sleeping room during their stay was $2266 \mathrm{ppm}$ and 2373 ppm, respectively. A higher average concentration occurred on the day with a higher attendance, which confirms the dependence of the $\mathrm{CO}_{2}$ concentration on the number of people in the room.

On the day with low outdoor air PM2.5 concentration (7 December 2020) in nursery B4, the indoor $\mathrm{CO}_{2}$ air quality was good and much better than in nursery B1. In the middle of the day, when the children were in another room, the playroom was ventilated intensively, and after nap time, the $\mathrm{CO}_{2}$ concentration dropped to $580 \mathrm{ppm}$. In the afternoon, the 
$\mathrm{CO}_{2}$ concentration increased, and despite the short-term airing of the room, there was no significant decrease in the $\mathrm{CO}_{2}$ concentration in the playroom.

The greatest differences in the $\mathrm{CO}_{2}$ and PM2.5 concentrations were recorded on 14 December 2020 when a high concentration of PM2.5 in the outdoor air was recorded. In nursery B1, the concentration of PM2.5 in the indoor air remained constant throughout the day, similar to 7 December 2020, except that due to the higher concentration outside, the concentration inside was higher. In nursery B4, the concentration of PM2.5 ranged from 20 to $75 \mu \mathrm{g} / \mathrm{m}^{3}$. The playroom was ventilated in the morning- $\mathrm{CO}_{2}$ levels dropped with a simultaneous increase in PM2.5. The next airing took place on 7 December 2020 when the children were in the sleeping room. When the playroom was aired and $\mathrm{CO}_{2}$ levels dropped to $580 \mathrm{ppm}$, an increase in PM2.5 to $50 \mu \mathrm{g} / \mathrm{m}^{3}$ was recorded. Another increase in PM concentration took place during the afternoon airing of the room; at the end of the day, the concentration of PM2.5 was $\sim 40 \mu \mathrm{g} / \mathrm{m}^{3}$.

These results show that airing the rooms during periods of high outdoor air particulate matter pollution resulted in higher PM levels indoors as well. By airing the rooms, the average $\mathrm{CO}_{2}$ concentration for the day can remain low (below $1200 \mathrm{ppm}$ ), but ventilation can result in high PM concentrations. Therefore, airing in winter is not a good way to ensure proper air quality. Figure 5 shows the average values of $\mathrm{CO}_{2}, \mathrm{PM} 2.5$, and PM10 concentrations in the nursery playrooms on the days of the winter measurement period $(\mathrm{W})$, divided into three periods of the nursery functioning - morning time (MT), nap time (NP), afternoon time (AT).

(a)

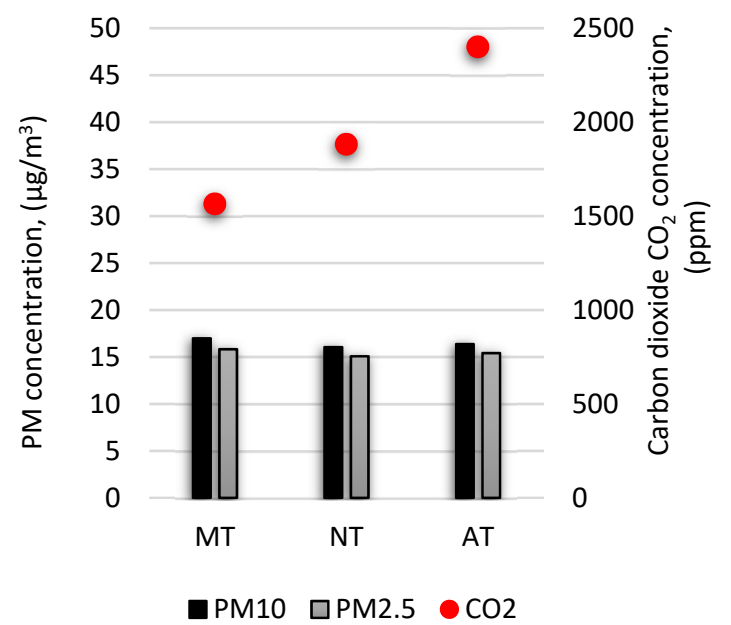

(c)

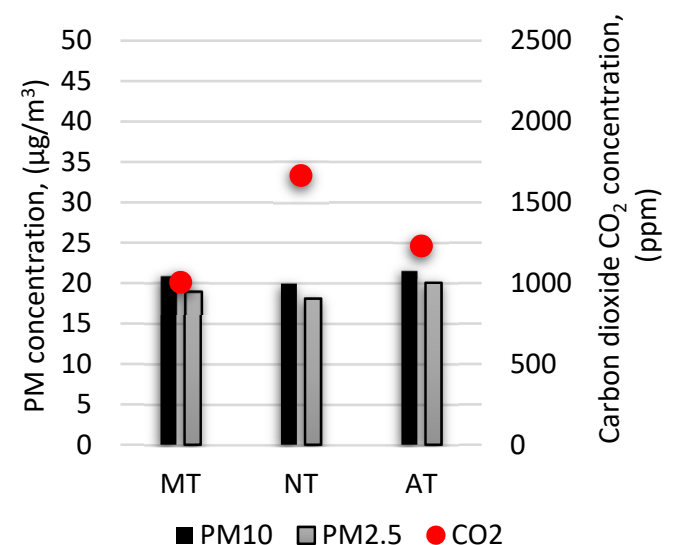

(b)

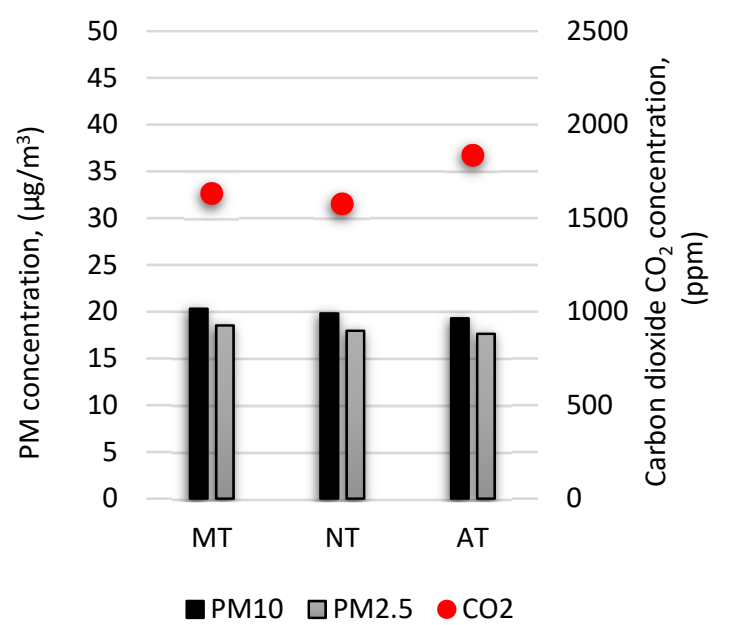

(d)

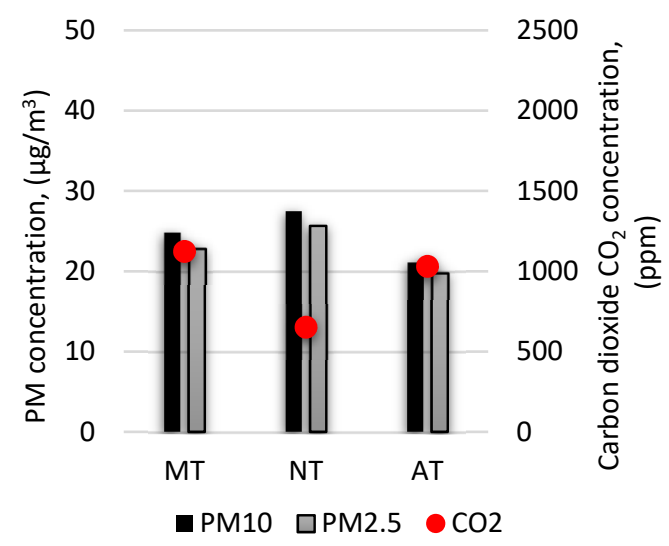

Figure 5. The concentrations of PM10, PM2.5, and $\mathrm{CO}_{2}$ when children stay in the playroom in the three periods of the nursery operation (a) B1, (b) B2, (c) B3, and (d) B4. 
Analyzing the average concentration of $\mathrm{CO}_{2}$ divided into three periods of the day with different purposes, along with the average concentration of dust illustrated several points:

- In nursery B1, with the worst indoor air quality, the concentration of $\mathrm{CO}_{2}$ increases throughout the day. This is related to the lack of room ventilation. At the same time, the concentration of particulate matter remains constant throughout the day.

- In nursery $\mathrm{B} 2$, the $\mathrm{CO}_{2}$ concentration in the middle of the day is slightly lower than in the morning and increases again after nap time. A constant, lower value of $\mathrm{CO}_{2}$ during nap time was due to the lack of occupants and decreased respiration. The PM concentration remained constant throughout the day, which indicated a lack of airing.

- In nursery B3, which uses the same room for sleeping and playing, the concentration of $\mathrm{CO}_{2}$ increases from morning until the end of nap time. The room is not ventilated. Airing takes place after the nap ends, indicated by a decrease in $\mathrm{CO}_{2}$ concentration and an increase in particulate matter concentration.

- In nursery $\mathrm{B} 4$, with the lowest average $\mathrm{CO}_{2}$ concentration, there was an influence from intensive room ventilation when the children were in another room. The concentration of $\mathrm{CO}_{2}$ dropped significantly, while the concentration of PM increased. Thanks to airing, the average concentration of $\mathrm{CO}_{2}$ throughout the day remained low, but this resulted in high levels of particulate matter.

For two selected nurseries (the worst situation in terms of the average $\mathrm{CO}_{2}$ concentration during the children's stay in the nursery (B1) and the best situation (B4)), where a clear effect of airing on the improvement of indoor air quality was noticed (Figure 6, below) carbon dioxide and the PM2.5 concentrations are shown for 11 December 2020. The average daily $\mathrm{CO}_{2}$ concentration during the children's stay in the nursery was close to the average $\mathrm{CO}_{2}$ concentration determined during the entire winter $(\mathrm{W})$. In Figure 6 vertical gray areas indicate when the windows were opened in the given rooms.

(a)

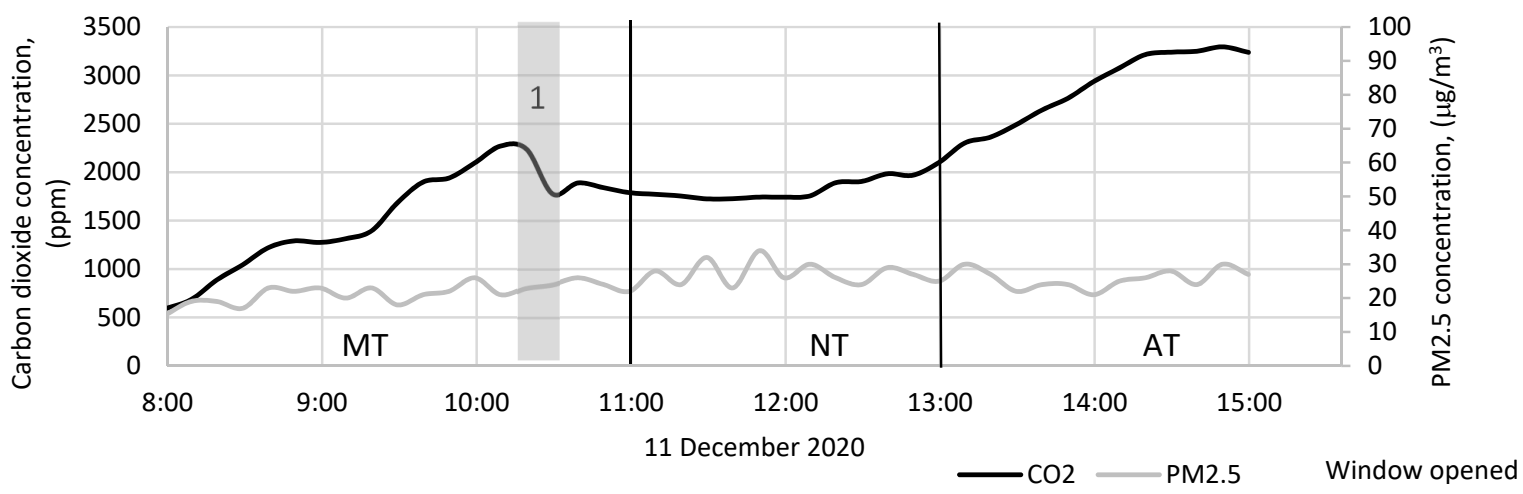

(b)

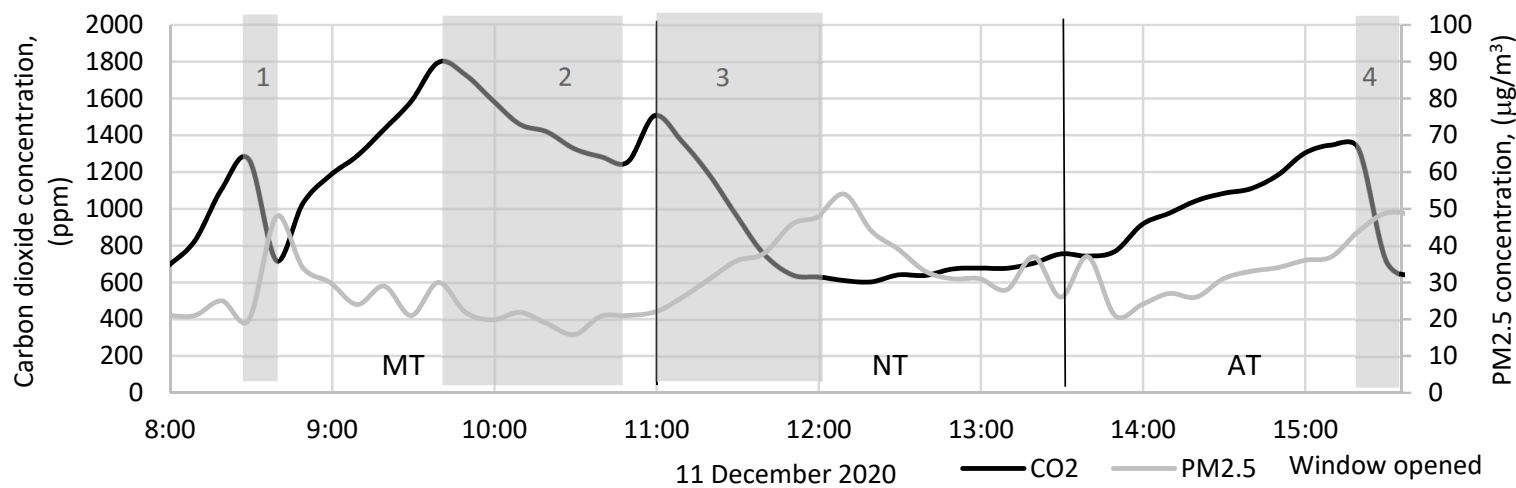

Figure 6. Room use in terms of airing the nursery playrooms, (a) B1, (b) B4. 
The way of the usage of the playroom in the nursery $\mathrm{B} 1$

In the morning (MT), $\mathrm{CO}_{2}$ concentrations increase from $500 \mathrm{ppm}$ (average nightly value) to $2240 \mathrm{ppm}$. A short 10-min airing (1), which is the only one that day, reduces the $\mathrm{CO}_{2}$ concentration by $500 \mathrm{ppm}$, which increases when the window is closed. During the nap period (NT), when the children are in another room, the concentration of $\mathrm{CO}_{2}$ remains constant, which indicates no $\mathrm{CO}_{2}$ emissions and no ventilation. The slight increase in $\mathrm{CO}_{2}$ concentration from 12:45 was affected by the slow return of children to the playroom after the nap. A sharp increase in $\mathrm{CO}_{2}$ levels was observed in the afternoon time (AT) when all the children were back in the playroom and $\mathrm{CO}_{2}$ levels reached $3295 \mathrm{ppm}$. The concentration of PM2.5 on the day of low external air pollution, even when opening the window, did not increase in the indoor air.

Playroom usage in nursery B4

The airing in the playroom in nursery B4 occurs at least four times a day (Figure 6b). When children are in the playroom in the morning (from 8:00 to 11:30), the $\mathrm{CO}_{2}$ concentration increases until the window is opened (1), reaching $1270 \mathrm{ppm}$. During the short-term opening of the window ( $15 \mathrm{~min}$ ), the $\mathrm{CO}_{2}$ concentration drops sharply by $450 \mathrm{ppm}$. After closing the window for $60 \mathrm{~min}$, the $\mathrm{CO}_{2}$ concentration increases from $720 \mathrm{ppm}$ to $1800 \mathrm{ppm}$. During the next $60 \mathrm{~min}$ when the window was open (2), the $\mathrm{CO}_{2}$ concentration decreases, related to the supply of outdoor air with low $\mathrm{CO}_{2}$ levels into the room. At 11:00, the children moved into another room and started nap time (NT). Only the babysitters remained in the playroom. At that time, a window was opened (3), which led to a decrease in $\mathrm{CO}_{2}$ concentration to $600 \mathrm{ppm}$, with no $\mathrm{CO}_{2}$ emissions from children in the room and low $\mathrm{CO}_{2}$ concentration in the outdoor air. This value remains relatively constant until 1:30 pm. The $\mathrm{CO}_{2}$ concentration increases again (to $1380 \mathrm{ppm}$ ) during the afternoon (AT) due to the return of children to the room.

\subsection{Concentration of Particulate Matter in Indoor and Outdoor Air}

The problem of poor air quality is particularly important during winter when people spend most of the day indoors, and the quality of outdoor air described by the concentrations of PM is worse than in summer. To determine the effect of the value of PM concentration in the outdoor air on the PM concentration in the indoor air, the winter measurement period is shown, which describes the quotients of PM2.5 and PM10 concentrations in indoor and outdoor air-respectively: I/O $\mathrm{O}_{\mathrm{PM} 2.5}$ and I/O $\mathrm{O}_{\mathrm{PM} 10}$ (Figure 7).

Periods when PM concentrations in the outdoor air are lowest (4 December 2020 and 7 December 2020 ) yielded the highest I/OPM2.5 and I/OPM10 indexes. For the remaining days, i.e., those when the average daily particulate matter concentration was above $55 \mu \mathrm{g} / \mathrm{m}^{3}$, the indicator value was similar and remained relatively constant. The average I/ $\mathrm{O}_{\mathrm{PM} 2.5}$ ratios for individual nurseries with its standard deviations were: $\mathrm{B} 1,0.16 \pm 0.02 ; \mathrm{B} 2,0.16 \pm 0.08$; $\mathrm{B} 3,0.18 \pm 0.04 ; \mathrm{B} 4,0.21 \pm 0.05$, and I/O $\mathrm{O}_{\mathrm{PM} 10}$ : B1 $0.18 \pm 0.02 ; \mathrm{B} 2,0.19 \pm 0.07 ; \mathrm{B} 3,0.17 \pm 0.04$; $\mathrm{B} 4,0.21 \pm 0.05$. The highest $\mathrm{I} / \mathrm{O}$ ratio values for both PM2.5 and PM10 came from nursery B4, i.e., the nursery with the best air quality in terms of $\mathrm{CO}_{2}$ concentration, in which the most intense airing occurs.

\subsection{Indoor Air Quality and Traffic}

The emission intensities calculated based on the number, group of vehicles, and concentrations of toxic components from actual tests were compared to the concentrations of components measured inside the premises. Due to fluctuations in the number and type of vehicles, as well as the measurements carried out inside the nurseries, the results were averaged into a polynomial trend line. Such an approximation makes it possible to determine trends in the results and the potential for comparison to one another. 
(a)

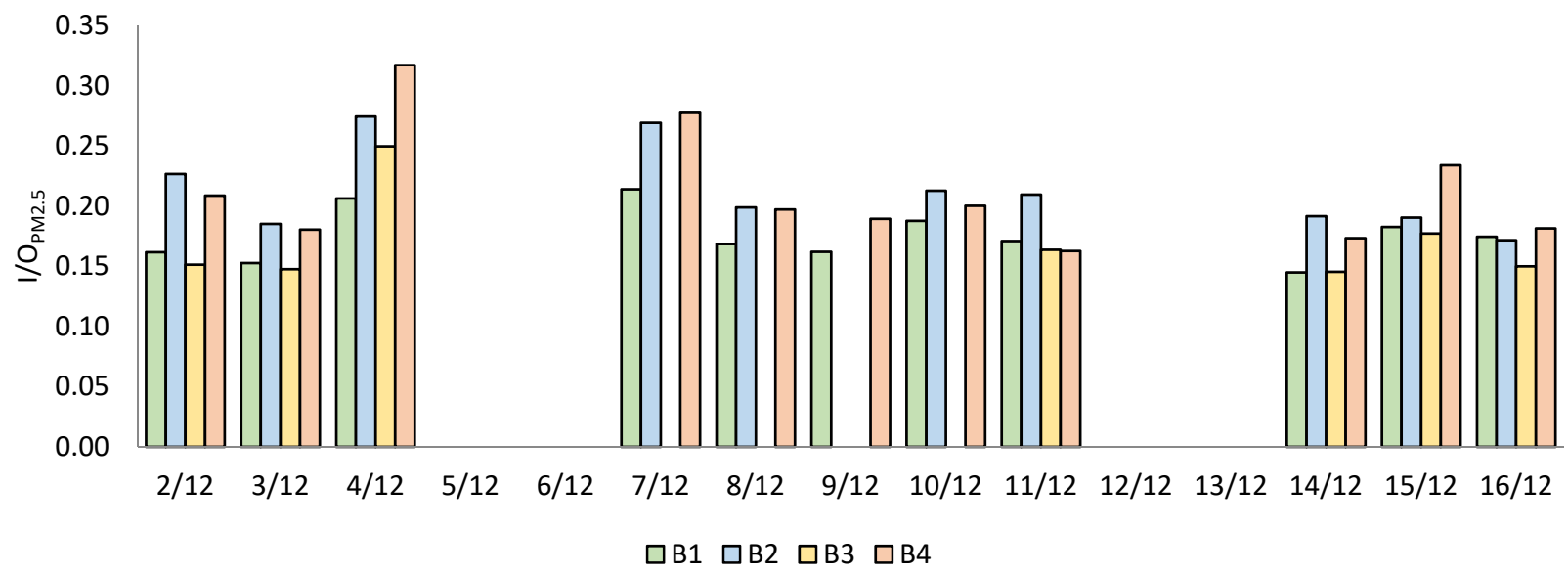

(b)

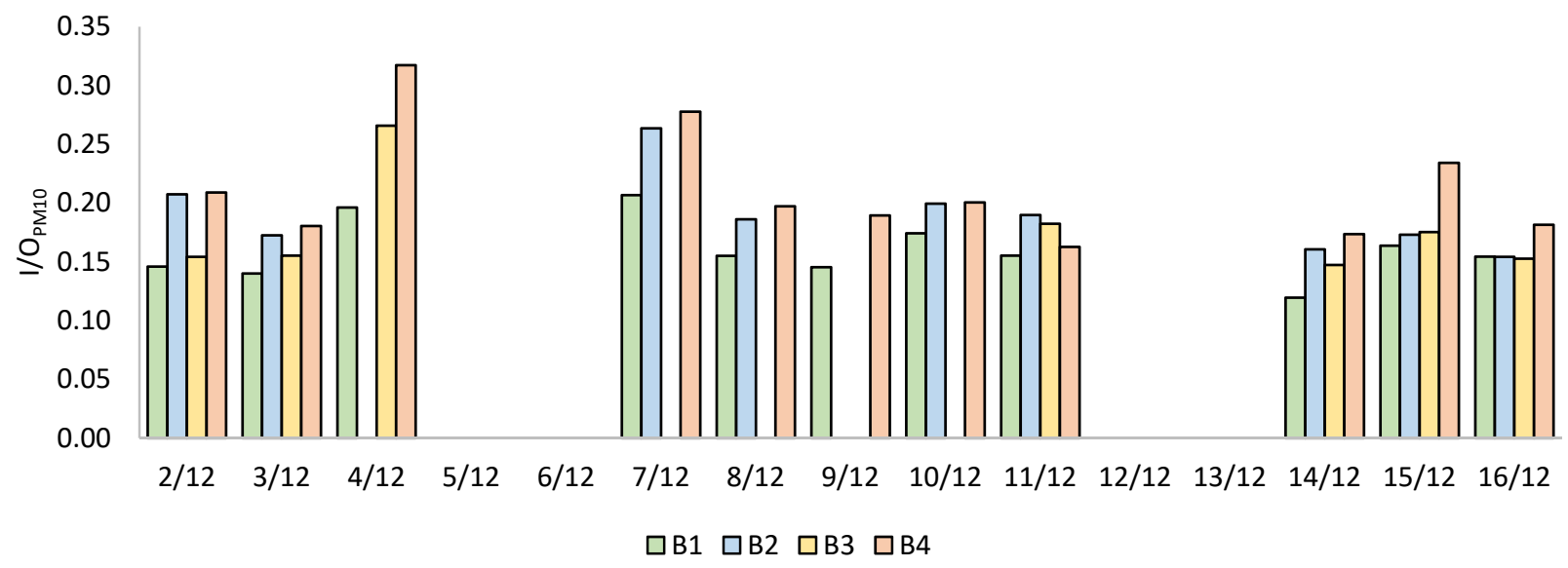

Figure 7. Average ratio of particulate matter concentration in indoor to outdoor air in the winter, (a) I/OPM2.5, (b) I/OPM10.

\subsubsection{Measurements near the Building B1\&B2}

Measurements were conducted on a one-way street. The device was placed approximately $30 \mathrm{~m}$ from the building. Therefore, measurements were conducted with a three-second delay. Transport traffic was assessed in the winter (W) and late spring (LS). Figure 8 shows the location of the measuring device (Figure 8a) and the place of the measurement (Figure $8 b$ ) and the structures of passing vehicles during winter (W) (Figure 8c) and late spring (LS) (Figure 8d).

The number of a given type of vehicle traveling on a given street was similar during the winter and late spring measurements, the vast majority were passenger vehicles. The traffic was light and there were only 46 cars per hour during measurement.

The graphs shown in Figure 9 compared the emission intensities with the PM10 and $\mathrm{CO}_{2}$ concentration levels inside four rooms in the building with nurseries B1 and B2.

It is difficult to find a relationship for spring in the graph of PM concentration dependence in rooms and the intensity of emissions caused by traffic (Figure 9b). In winter (Figure 9a), the only similarity is for the playroom of nursery B1, where the values slowly decreased over time, but only for PM10. When analyzing the concentration of carbon dioxide, the concentration trend differed from the emission intensity trend. The concentration in the rooms increased, which was directly influenced by people, not by traffic, which decreased over time.

In late spring (Figure 9b), carbon dioxide generally increases over time as the emission intensity was measured in the sleeping room of nursery B2, but this is probably due to the 
presence of people and not to traffic. For PM, it is difficult to find similarities during the emission and concentration curves, as they were quite different.

(a)

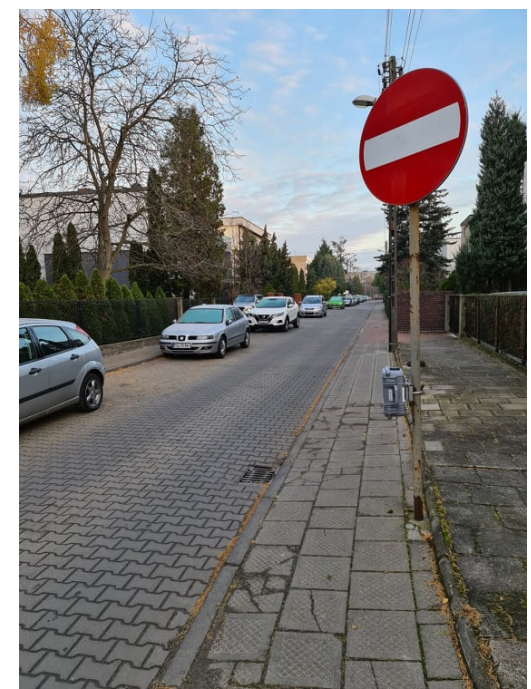

(c)

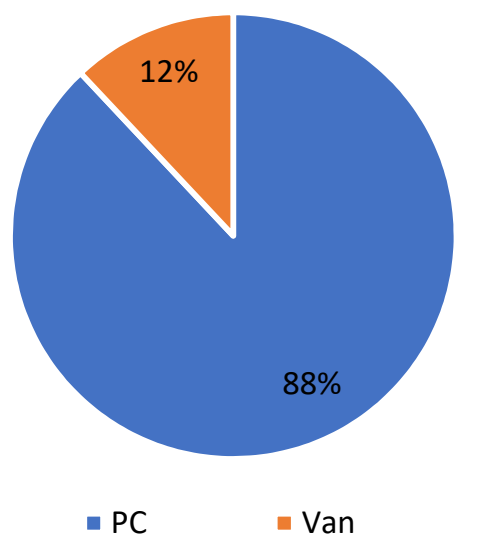

(b)

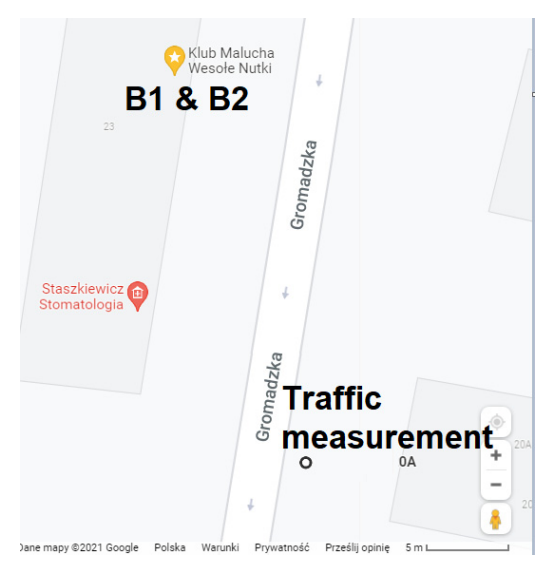

(d)

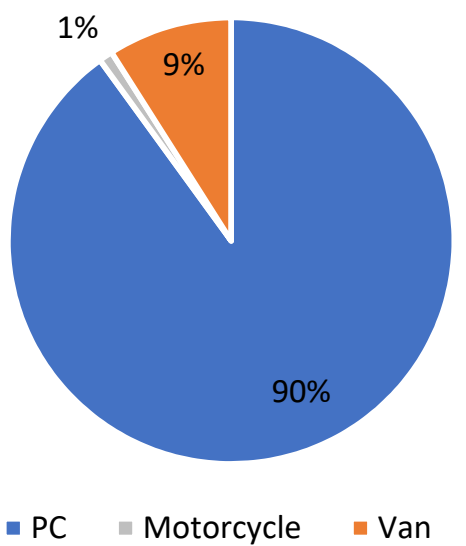

Figure 8. Traffic intensity test: (a) view of the installed device near building B1\&B2, (b) view of the distance between B1\&B2 [Source: Google Maps], and apparatus (c) percentage of vehicles depending on their category and emission class in winter (W), (d) in late spring (LS).

The average number of vehicles during the winter was greater (7.3 vehicles per $10 \mathrm{~min}$ ) than in the spring ( 4.5 vehicles per $10 \mathrm{~min}$ ). The emission intensity curves for winter and late spring differ; the values during the spring were several times lower and were caused by less traffic. The curves are different and it is difficult to find even small similarities.

\subsubsection{Measurements near the Building B3}

Near building B3, the traffic measurement apparatus was located approximately $50 \mathrm{~m}$ from the facility, next to a busy two-lane road (Figure 10a). The research site is located inside the large-size building on the first floor and is certainly subject to the impact of road traffic on indoor air quality. The traffic were much higher than in B1\& B2 and there were 359 cars per hour. 
(a)

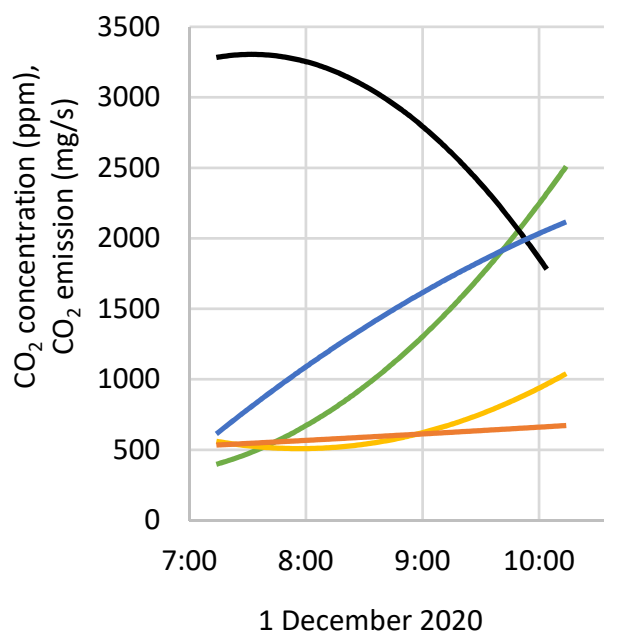

1 December 2020

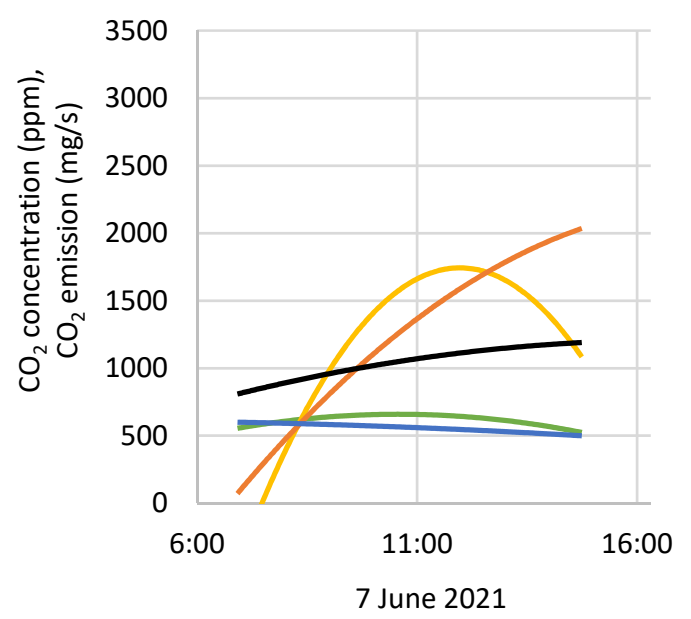

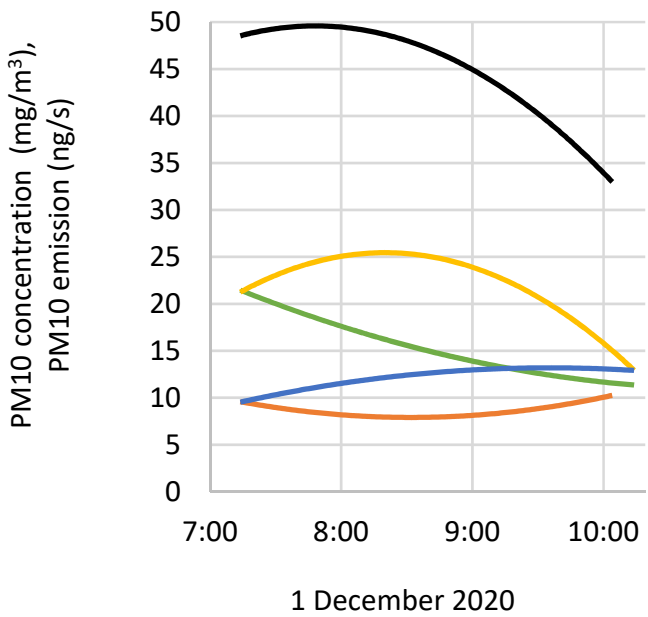

(b)
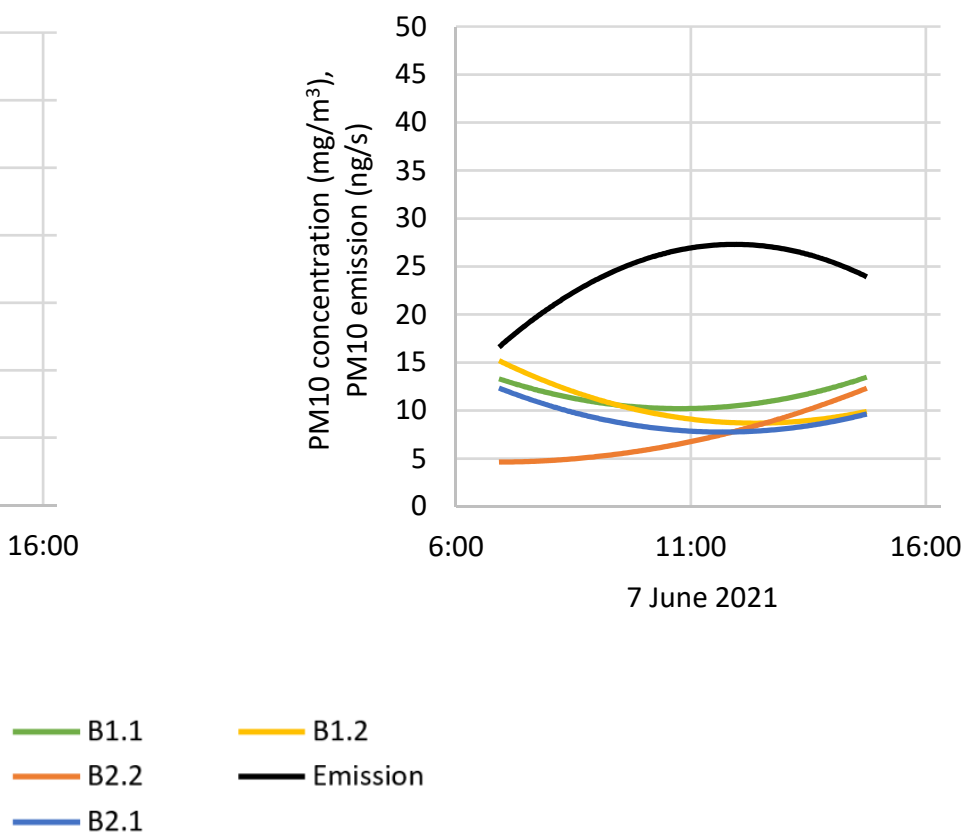

Figure 9. Trend lines for the intensity of PM emissions and PM10 concentration as well as the intensity of $\mathrm{CO}_{2}$ emissions and $\mathrm{CO}_{2}$ concentration in nursery rooms of building B1\&B2 (a) for winter (W), (b) for late spring (LS).

The percentage share of vehicles and the structure of passing vehicles are shown in Figure $10 \mathrm{~b}$ for the winter $(\mathrm{W})$.

The measured concentration values differ relative to the emission intensity (Figure 11). Only one of the curves (PM10 concentration in the sleeping room) achieved a specific intensity of emissions from communication sources. However, this did not cause major changes in the playroom PM10 concentrations, where a significant increase and then decrease in this concentration was measured. The remaining measurements showed the separate nature of pollutant concentrations relative to traffic, which leads again to the conclusion that there is no direct impact on indoor air quality. 
(a)

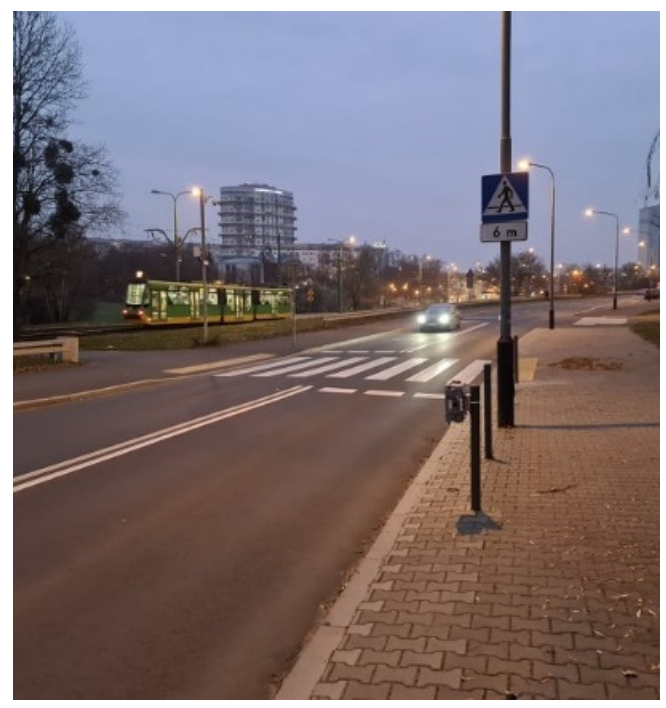

(b)

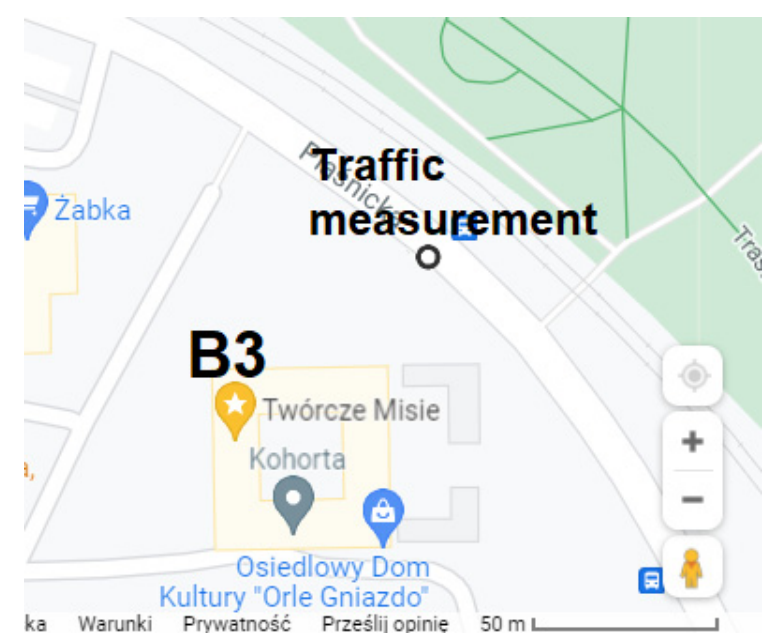

(c)

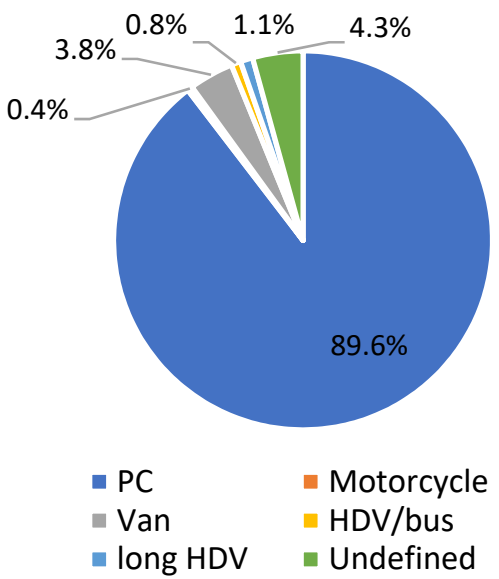

Figure 10. Traffic intensity test: (a) view of the installed device near test point B3, (b) view of the distance between B3 and apparatus [Source: Google Maps], (c) percentage of vehicles depending on their category and emission class.

(a)

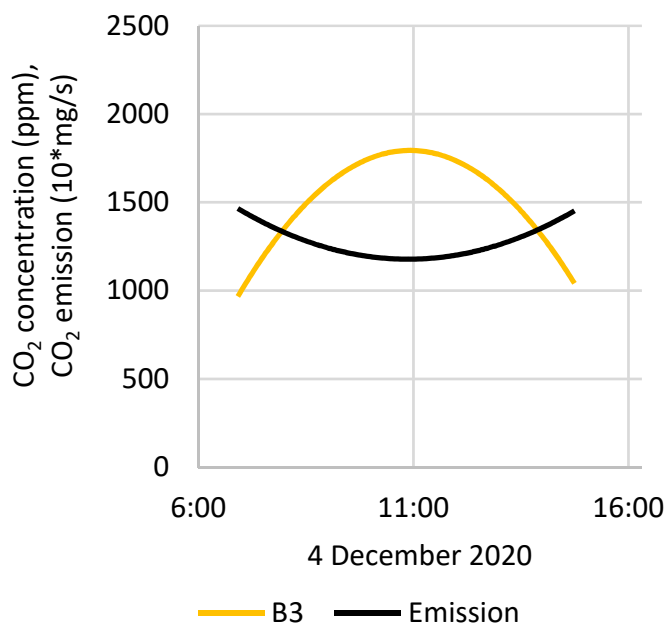

(b)

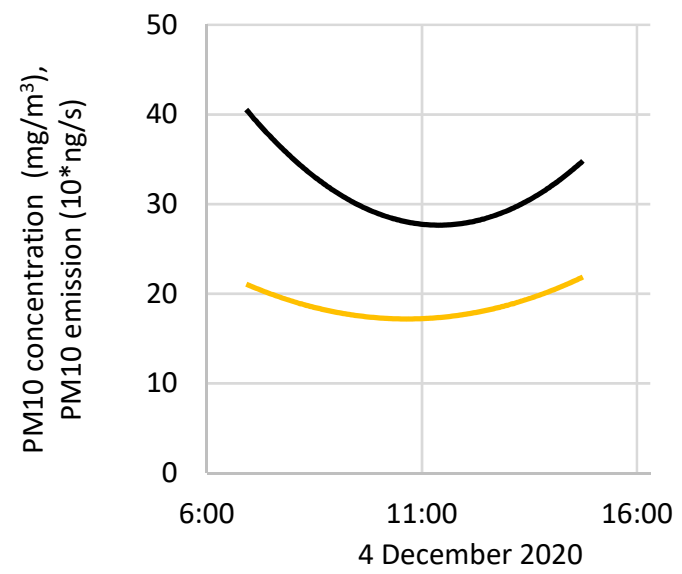

Figure 11. Trend lines for the intensity of (a) PM emissions and PM10 concentrations as well as the intensity of (b) $\mathrm{CO}_{2}$ emissions and $\mathrm{CO}_{2}$ concentrations in nursery room $\mathrm{B} 3$. 


\subsubsection{Measurements near Building B4}

The measurement took place $\sim 80 \mathrm{~m}$ from the facility, next to a very busy 3-lane road. The separation of the third lane and the movement of vehicles at short distances from each other resulted in a large percentage of unidentified vehicles (Figure 12). The volume of traffic was quite high and there were 613 cars per hour.

(a)

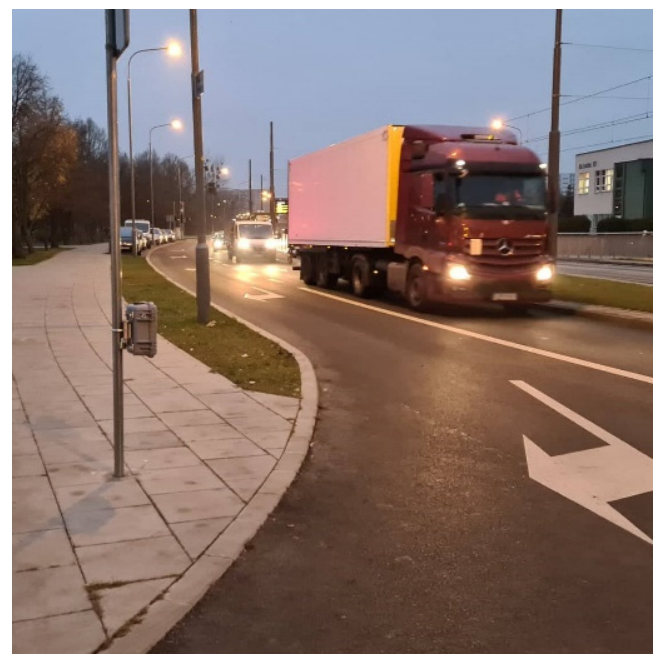

(b)

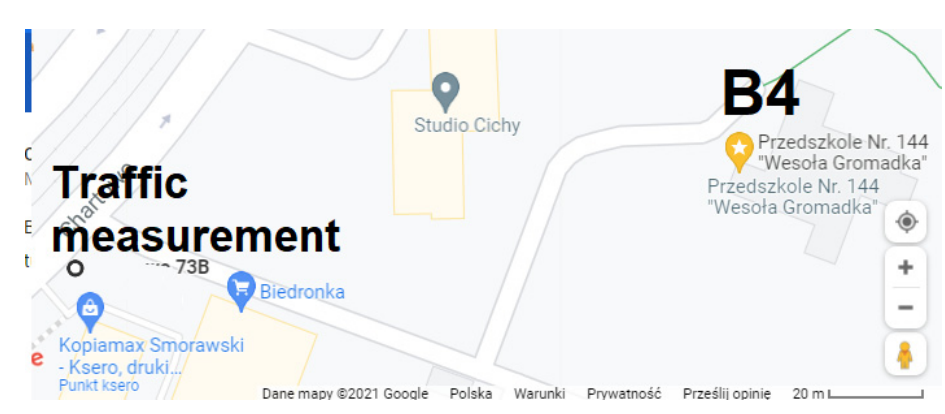

(c)

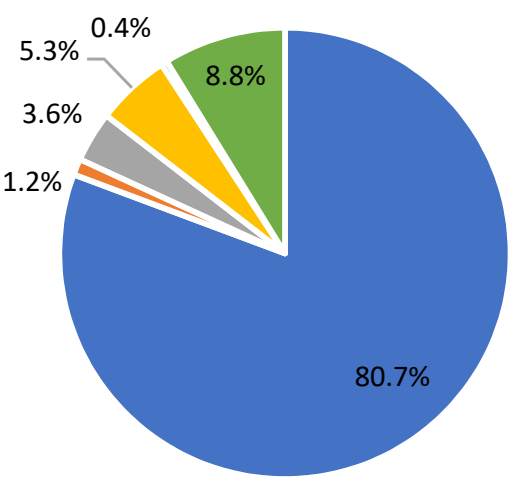

$$
\begin{array}{lll}
-\mathrm{PC} & \quad \text { Motorcycle } & \quad \text { Van } \\
-\mathrm{HDV} / \mathrm{bus} & - \text { long HDV } & - \text { Undefined }
\end{array}
$$

Figure 12. Traffic intensity test: (a) view of the installed device near test point $B 4,(\mathbf{b})$ view of the distance between $B 4$ and apparatus [Source: Google Maps], (c) percentage of vehicles depending on their category and emission class.

For the B4 facility, similar results were obtained for the PM10 emission intensity in the playroom. The course of the emission intensity and the concentration inside the playroom slightly increased initially and decreased in the middle of the measurement cycle. (Figure 13). These relationships did not apply to the sleeping room. Again, vehicle emissions apparently did not affect the air quality inside the rooms. 
(a)

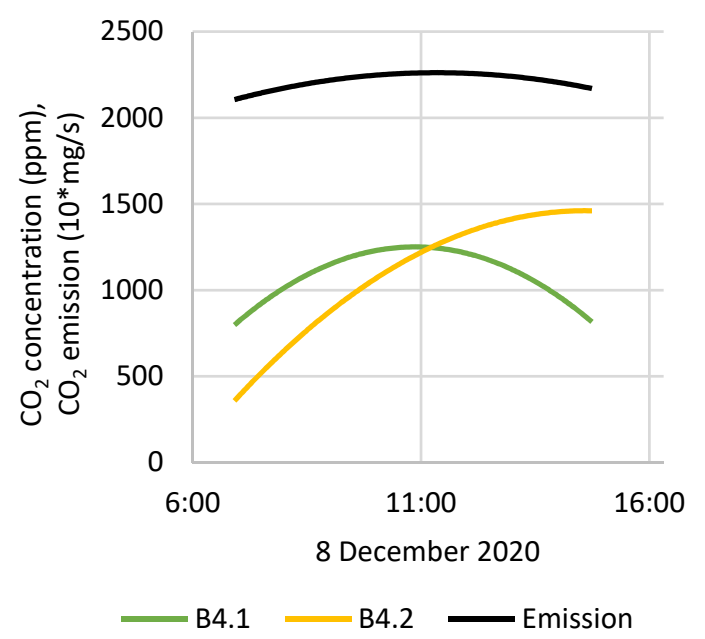

(b)

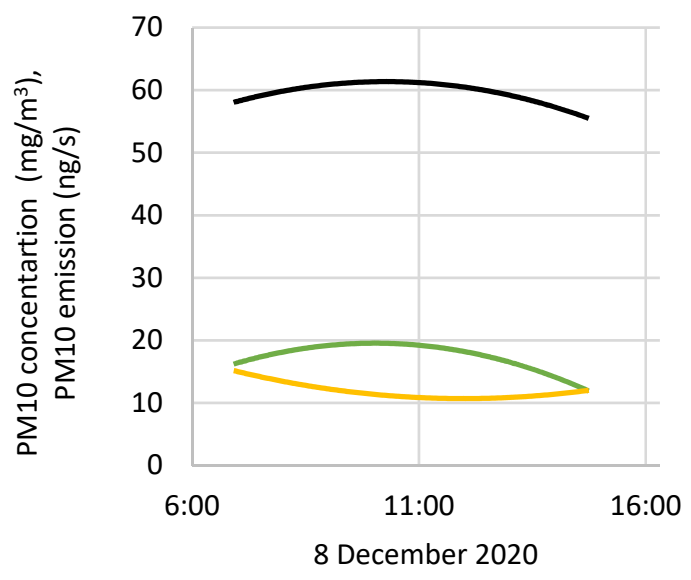

Figure 13. Trend lines for the intensity of (a) PM emissions and PM10 concentrations as well as the intensity of (b) $\mathrm{CO}_{2}$ emissions and $\mathrm{CO}_{2}$ concentrations in nursery $\mathrm{B} 4$.

\section{Discussion}

These results yielded valuable insights in terms of the assessment of selected air quality parameters and identifying potential reasons for poor indoor air quality.

\section{1. $\mathrm{CO}_{2}$ Concentration}

In winter, in three of four nurseries, high average $\mathrm{CO}_{2}$ concentrations were obtained: for B1, $2017 \pm 204 \mathrm{ppm}$; for B2, $1637 \pm 137 \mathrm{ppm}$; and B3, $1794 \pm 185 \mathrm{ppm}$. These results significantly exceeded permissible levels (1500 ppm). Exceeding permissible $\mathrm{CO}_{2}$ concentration levels frequently occurs in educational rooms due to the lack of mechanical ventilation [24,25]. Our research results have been confirmed by other authors. Canha [26] obtained high levels of $\mathrm{CO}_{2}(1200 \pm 400 \mathrm{ppm})$ in studies carried out in France. According to research by Stankevic and Lesinskis [27], 75 percent of the educational institutions with natural ventilation (in Latvia) exceeded $1000 \mathrm{ppm}$ carbon dioxide, with a maximum value of $1356 \mathrm{ppm}$. In other studies [24], the average concentration of $\mathrm{CO}_{2}$ in 17 educational institutions was analyzed, the median was $1400 \mathrm{ppm}$, and the maximum concentration was $3613 \mathrm{ppm}$. In 63 percent of facilities, $\mathrm{CO}_{2}$ levels exceeded $1000 \mathrm{ppm}$. In research conducted in the Netherlands [28], the mean value in the sleeping room was $1266 \mathrm{ppm}$ (maximum of $1834 \mathrm{ppm}$ ), and the playroom was 1104 ppm (max 2271 ppm). In a two-week study conducted at educational institutions in Portugal during the winter and spring with natural ventilation [25], air quality results were also bad: the median $\mathrm{CO}_{2}$ concentration in winter was 1563 ppm (max 2178 ppm) and in spring 1377 ppm (max 2750 ppm). Only one nursery in our study, (B4), had satisfactory average $\mathrm{CO}_{2}$ concentration levels in the winter $(1155 \pm 150 \mathrm{ppm})$. It was a facility where frequent and long-term airing was used.

Our research also covered the period outside the heating season (LS). In late spring, the concentration of carbon dioxide in the rooms was lower than in winter, which qualified the air quality as good. The average daily level in nursery B1 was $1157 \pm 86$ ppm, in nursery B2 it was $910 \pm 74 \mathrm{ppm}$. This agreed with studies published by Canha et al. [26], who noted $\mathrm{CO}_{2}$ concentrations were lower in the late spring than during the heating season.

\subsection{Particulate Matter Concentration}

Most often, the concentration of particulate matter in indoor air is lower than in outdoor air, which indicates that outdoor air is the source of particulate matter in Poland [29]. Measurements indicated that the lowest PM concentration in the winter period occurred on 7 December 2020. At the same time, it was the day with the highest wind speed (almost $30 \mathrm{~km} / \mathrm{h}$ ). This confirms that atmospheric conditions may influence the PM concentra- 
tion [23]. The worst day for particulate matter concentration was on 14 December 2020 when the maximum concentrations for PM2.5 and PM10 were $235 \mu \mathrm{g} / \mathrm{m}^{3}$ and $343 \mu \mathrm{g} / \mathrm{m}^{3}$, respectively. Those results confirm a very high particulate matter pollution problem in Poland [30].

The outdoor air quality analysis results show that PM concentrations are characterized by seasonality in countries with a cold and temperate climate. Higher concentrations of PM were recorded in the winter and that characterization was confirmed when particulate matter decreases were observed when the external air temperature increased. We concluded the dominant source of pollution was low emission from heat sources used to heat buildings located near the analyzed facilities. This confirmed results reported by other authors that indicated that particulate matter concentrations increased during the heating season $[9,23,26,31]$, and the heating season is the greatest predictor of indoor particulate matter concentration [32]. In research from Portugal [25], the PM10 concentration was $75 \mu \mathrm{g} / \mathrm{m}^{3}$ in the winter and $60 \mu \mathrm{g} / \mathrm{m}^{3}$ in the spring. The sources of particulate matter and its seasonality were not analyzed by the authors, but the concentrations in spring were lower than in winter, in contrast to research in Poland. This may indicate other sources of particulate matter than heating buildings, as the climate in Portugal is warmer than in Poland.

\subsection{Airing of Rooms and Its Impact on Indoor Air Quality}

The good air quality in the room, which means that there is a good air exchange, may be described with the level of carbon dioxide concentration in the room [33]. According to the literature, $\mathrm{CO}_{2}$ concentrations that indicate good air exchange are 1000 $1500 \mathrm{ppm}[12,13]$. The main reason for the high concentration of $\mathrm{CO}_{2}$ in rooms is the lack of mechanical ventilation and the insufficient frequency of opening windows when the rooms are in use [12,34]. Airing the rooms several times a day lowers the constantly increasing concentration of $\mathrm{CO}_{2}$ in the room. Nursery $\mathrm{B} 4$, with the lowest $\mathrm{CO}_{2}$ concentration in the winter, was intensively aired (Figures $5 \mathrm{~d}$ and $6 \mathrm{~b}$ ). Even $15 \mathrm{~min}$ of airing the room reduced the $\mathrm{CO}_{2}$ concentration by up to $450 \mathrm{ppm}$. In nursery $\mathrm{B} 1$, with the worst levels of $\mathrm{CO}_{2}$, airing took place sporadically (Figure 6a). Very high levels of $\mathrm{CO}_{2}$ at the end of the day in playrooms B1 and B2 were $2400 \mathrm{ppm}$ and $1800 \mathrm{ppm}$, respectively, and resulted from the lack of room ventilation. Even if the reason for the lack of ventilation is the fear of lowering the temperature of the internal air during the winter, when the outside temperature is low (the average outside temperature in winter $(\mathrm{W})$ was $3.2^{\circ} \mathrm{C}$ ), rooms still need adequate ventilation. With an efficiently operating heating system, the internal air temperature will return to normal relatively quickly with a short-term supplier of cold outside air. In institutions where a different room is intended for the midday nap, the lack of airing the playroom during this time is unjustified. Facility B3 does not have a separate sleeping room, all activities take place in one room, and the highest concentration of $\mathrm{CO}_{2}$ was recorded in the middle of the day, (nap time, $1700 \mathrm{ppm}$ ). Airing the room after a nap during lunch resulted in a $\mathrm{CO}_{2}$ concentration reduction by $500 \mathrm{ppm}$.

Unfortunately, airing the rooms, which lowers the $\mathrm{CO}_{2}$ concentration, involves the direct introduction of outside air into the room. In nursery B4, the rooms were aired during naps, but that increased the particulate matter. Therefore, airing is not an ideal method to ensure proper air quality, especially in locations with high outdoor air pollution. It can only be effective when the outside air quality is good. Studies conducted during the late spring confirmed this. In two nurseries, B1 and B2, with comparable LS and W attendance numbers, the average $\mathrm{CO}_{2}$ concentration in June was assessed (average outside air temperature, $22.7^{\circ} \mathrm{C}$; B1, $1157 \pm 86 \mathrm{ppm}$; B2, $910 \pm 74 \mathrm{ppm}$ ). Despite the poor air quality during the winter, common for rooms with natural ventilation $[11,26,35,36]$, air quality in the spring was good. The particulate matter concentration was also very low $\left(\mathrm{B} 1,7 \pm 2 \mu \mathrm{g} / \mathrm{m}^{3} ; \mathrm{B} 2,6 \pm 2 \mu \mathrm{g} / \mathrm{m}^{3}\right)$. Therefore, good indoor air quality in terms of $\mathrm{CO}_{2}$ and PM can be achieved by airing the rooms. The necessary condition is good outside air quality with sufficiently intense ventilation. Ventilation affects both the concentrations of 
particulate and gaseous particles indoors, but the effects on each may be different due to differences in the physical nature of the pollutants and the characteristics of the sources [37].

\subsection{Traffic}

These results indicated a small and ambiguous impact of road traffic on indoor air quality parameters in the nursery. This may be related to the significant distance from busy streets. The research was carried out at times where the impact could have been caused by heating sources for single-family houses located close to building B1\&B2. Repetition of these tests in June, beyond the heating season, still did not indicate any impact of traffic on the concentrations of pollutants inside the rooms. Concentrations of selected compounds in the air, compared to the traffic of vehicles, show different curves with constant traffic. Carbon dioxide measurements show that changes in its concentration come from people staying in buildings. There is no visible effect of road traffic on the concentration of toxic compounds in all analyzed cases. The approximation of emissions from individual vehicles could also have an impact on the measurements. Those differences may be related to, inter alia, their poor technical condition. Taking into account the number of measurements made in several places, it is worth noting the degree of distinctiveness of the emission intensity curves approximated by the 2-degree polynomial in relation to air measurements indicated the independence of these indicators $\left(\mathrm{CO}_{2}\right.$ and $\left.\mathrm{PM}\right)$.

Based on an assessment of the number of cars passing near one of the nurseries during the winter and late spring, car transport is not seasonal since a similar number of passing cars was obtained. This research did not confirm the influence of the building location relative to busy streets on the quality of indoor air. This may be because nurseries are located deep in the housing estate or on quieter streets.

\subsection{Possibilities to Improve Indoor Air Quality}

Obtaining better indoor air quality requires searching for solutions that improve outdoor air quality, examples of which come from research conducted in Taiwan [38] or China [39]. There are different guidelines on how ventilation can be improved in existing buildings. Air quality in facilities with mechanical ventilation is usually good, and the advantage of using mechanical ventilation is the ability to adjust the capacity to the current demand control ventilation (DCV) needs [40]. In order to improve air quality, a system could be designed to supply air to the bedroom, flow through the playroom, and exhaust from all rooms into the building hallway [28]. Decentralized units such as reversible fans [41] or façade units [42] also work well.

Conditions necessary for mechanical ventilation to improve air quality include the necessity to turn it on (which is sometimes a problem), excellent performance, and appropriate system and component settings [43]. Although there are attempts to introduce solutions that would support the already existing natural ventilation systems, their authors nevertheless suggest that the best way is to introduce mechanical ventilation. Mijakowski and Sowa proposed the use of humidity-controlled window ventilators. As a result, they lowered $\mathrm{CO}_{2}$ concentrations by an average of $500 \mathrm{ppm}$. The maximum levels were reduced from $4000 \mathrm{ppm}$ to $2800 \mathrm{ppm}$, but this was insufficient. In her research, Gładyszewska-Fiedoruk stated that in institutions such as kindergartens, air supply should not be regulated as a function of humidity, because in winter the central heating may affect humidity values. She proposed [44], similarly to Mijakowski and Sowa [45], to open the windows and instructed employees about the need to supply external air, and also suggested cleaning the chimneys of natural ventilation [46]. The use of mechanical ventilation, especially for outdoor air pollution, is essential [30]. Other previously mentioned advantages include the possibility of air filtering and the use of heat recovery [47]. The use of small, dedicated, one-room ventilation units does not have to be expensive [48]. 


\subsection{Limitations}

- The research was conducted in a limited time and space due to the prevailing COVID19 pandemic.

- Quantitatively analyzed concentrations of PM2.5 and PM10, without chemically analyzing the dust, so the conclusions are general and it is not possible to unequivocally assess the source of the dust.

- Traffic was assessed on one day near each nursery and should be assessed more frequently (more days, taking into account different seasons of the year).

\section{Conclusions}

Although research on air quality in educational buildings for young children has been extensive with a constant focus on indoor air quality in terms of $\mathrm{CO}_{2}$ concentration is not good, good solutions that could be successfully introduced on a large scale remain elusive. After analyzing these results, several research questions may be answered.

1. Can proper indoor air quality be ensured by airing the rooms?

Our results support the possibility of ensuring proper indoor air quality in nurseries, but it requires using proper ventilation strategies. It is not possible to lower the $\mathrm{CO}_{2}$ concentration in the indoor air without the introduction of outdoor air. Room ventilation when the outdoor air is polluted, which occurred in the analyzed locations, reduces the $\mathrm{CO}_{2}$ concentration but worsens the indoor air quality in terms of the PM concentration. However, PM levels in the indoor air may be influenced by infiltration of outdoor air through leaks in the building envelope; this suggests paying attention to building airtightness during building design.

The best solution is to use supply and exhaust ventilation systems with an appropriate method of preparing the outside air before its introduction and scrubbing particulate matter from the outside air.

2. Is there a correlation between indoor and outdoor PM concentrations and is it seasonal?

The analyses showed a correlation between PM concentration of indoor and outdoor air in each building. The I/O ratio ranged between 0.15 and 0.20 on most measurement days when the PM concentration outside was above $55 \mu \mathrm{g} / \mathrm{m}^{3}$. When the concentration outside was lower, the I/O ratio was higher. The highest $\mathrm{I} / \mathrm{O}$ ratios were recorded for nursery B4-the nursery in which airing was the most intensive and led to the best air quality in terms of the $\mathrm{CO}_{2}$ concentration $(1155 \pm 150 \mathrm{ppm})$. The lowest I/O values were recorded in nursery B1, $0.16 \pm 0.03 \mu \mathrm{g} / \mathrm{m}^{3}$ and $0.18 \pm 0.02 \mu \mathrm{g} / \mathrm{m}^{3}$. Alarmingly, this nursery also had the worst air quality in terms of $\mathrm{CO}_{2}$ concentration (2004 $\pm 191 \mathrm{ppm}$ ).

Seasonality in the PM2.5 and PM10 concentrations and their links to the outside air temperature was noticed.

3. Is there a correlation between seasonal traffic and indoor air quality?

Based on the analyses, no connection was found between traffic and the PM10 and $\mathrm{CO}_{2}$ concentration levels at indoor nurseries. The similarities in three cases seemed accidental and were not confirmed by simultaneous measurements conducted indoors.

Based on our analyses:

1. The absence of a ventilation system, or any other air supplier system, results in $\mathrm{CO}_{2}$ concentration increases in the room.

2. Ventilation by airing effectively ensures the proper indoor air quality, but only when outdoor air is not polluted.

3. When ventilating rooms by airing, monitoring the PM10 and PM2.5 concentrations in the external air is extremely important. When the PM2.5 concentration in the outdoor air is high (above $150 \mu \mathrm{g} / \mathrm{m}^{3}$ ), outdoor air should not be supplied to rooms.

4. When the concentration of particulate matter in the outdoor air was high, it was also high in the indoor air, which confirmed the influence of infiltration. 
5. Infiltration had the greatest impact on the PM concentration in indoor air regardless of the intensity of airing the rooms. The tends to change PM concentration levels in indoor air and was the same in each nursery.

6. The seasonality of particulate matter concentration in the outside air was shown.

7. No relationship was found between traffic and indoor PM10 and $\mathrm{CO}_{2}$ concentrations. Further research:

- Repeat the tests at additional facilities (including the ones in this study) and different times to confirm the seasonality of pollutants and the impact of the location of the facilities.

- In order to analyze the influence of infiltration, it is necessary to assess the airtightness indicators of the buildings and check whether the air that infiltrates the building through leaks can be cleaned using mechanical ventilation equipped with filters.

- The feasibility of using solutions for the improvement of indoor air quality suggested in the literature should be assessed.

- A campaign to educate employees of educational institutions about the need to improve air quality in terms of $\mathrm{CO}_{2}$ concentration should be conducted.

Author Contributions: Conceptualization, M.B., K.R., M.M., P.F. and M.S.; methodology, M.B., K.R., P.F. and M.S.; formal analysis, M.B., K.R.; data curation, K.R. and M.S.; writing-original draft preparation, M.B., K.R. and M.S.; writing-review and editing, M.B., K.R. and M.M.; visualization, K.R. and M.S.; supervision, M.B. and P.F.; project administration, M.B.; funding acquisition, M.B. All authors have read and agreed to the published version of the manuscript.

Funding: This research was funded by the Poznan University of Technology, grant number 3016/ SIGR/3335.

Institutional Review Board Statement: Not applicable.

Informed Consent Statement: Not applicable.

Data Availability Statement: Not applicable.

Acknowledgments: The authors would like to acknowledge the Directorate and Staff of the nurseries for the opportunity to conduct the research.

Conflicts of Interest: The authors declare no conflict of interest.

\section{References}

1. Yocom, J.E. Indoor-outdoor air quality relationships: A critical review. J. Air Pollut. Control Assoc. 1982, 32, 500-520. [CrossRef]

2. Lee, S.C.; Chan, L.Y.; Chiu, M.Y. Indoor and outdoor air quality investigation at 14 public places in Hong Kong. Environ. Int. 1999, 25, 443-450. [CrossRef]

3. Meier, R.; Schindler, C.; Eeftens, M.; Aguilera, I.; Ducret-Stich, R.E.; Ineichen, A.; Davey, M.; Phuleria, H.C.; Probst-Hensch, N.; Tsai, M.-Y.; et al. Modeling indoor air pollution of outdoor origin in homes of SAPALDIA subjects in Switzerland. Environ. Int. 2015, 82, 85-91. [CrossRef]

4. Snider, G.; Carter, E.; Clark, S.; Tseng, J.; Yang, X.; Ezzati, M.; Schauer, J.J.; Wiedinmyer, C.; Baumgartner, J. Impacts of stove use patterns and outdoor air quality on household air pollution and cardiovascular mortality in southwestern China. Environ. Int. 2018, 117, 116-124. [CrossRef] [PubMed]

5. Directive 2008/50/EC of the European Parliament and of the Council of 21 May 2008 on Ambient Air Quality and Cleaner Air for Europe. Available online: https:/ / op.europa.eu/en/publication-detail/-/publication/1ac2582f-048a-4afe-91ad-72e7cc066ec9 (accessed on 10 August 2021).

6. World Health Organization. WHO Air Quality Guidelines for Particulate Matter, Ozone, Nitrogendioxide and Sulfur Dioxide. Global Update 2005. Summary of Risk Assessment. 2005. Available online: http://apps.who.int/iris/bitstream/handle/10665/ 69477/WHO_SDE_PHE_OEH_06.02_eng.pdf?sequence=1 (accessed on 12 August 2021).

7. Parrish, D.D.; Xu, J.; Croes, B.; Shao, M. Air quality improvement in Los Angeles-Perspectives for developing cities. Front. Environ. Sci. Eng. 2016, 10, 11. [CrossRef]

8. Pugh, T.A.M.; MacKenzie, A.R.; Whyatt, J.D.; Hewitt, C.N. Effectiveness of Green Infrastructure for Improvement of Air Quality in Urban Street Canyons. Environ. Sci. Technol. 2012, 46, 7692-7699. [CrossRef] [PubMed]

9. Ji, W.; Wang, Y.; Zhuang, D. Spatial distribution differences in PM2.5 concentration between heating and non-heating seasons in Beijing, China. Environ. Pollut. 2019, 248, 574-583. [CrossRef] 
10. Siedlecki, M.; Galant, M.; Rymaniak, Ł.; Ziółkowski, A. Emission investigation from passenger car equipped with gasoline direct injection engine in real traffic conditions. Autobusy 2017, 12, 404-409.

11. Basińska, M.; Michałkiewicz, M.; Ratajczak, K. Impact of physical and microbiological parameters on proper indoor air quality in nursery. Environ. Int. 2019, 132, 105098. [CrossRef]

12. Asanati, K.; Voden, L.; Majeed, A. Healthier schools during the COVID-19 pandemic: Ventilation, testing and vaccination. J. $R$. Soc. Med. 2021, 114, 160-163. [CrossRef]

13. Burridge, H.C.; Bhagat, R.K.; Stettler, M.E.J.; Kumar, P.; De Mel, I.; Demis, P.; Hart, A.; Johnson-Llambias, Y.; King, M.-F.; Klymenko, O.; et al. The ventilation of buildings and other mitigating measures for COVID-19: A focus on wintertime. Proc. $R$. Soc. A Math. Phys. Eng. Sci. 2021, 477, 20200855. [CrossRef]

14. Wojtkowiak, J.; Amanowicz, Ł. Effect of surface corrugation on cooling capacity of ceiling panel. Therm. Sci. Eng. Prog. 2020, 19, 100572. [CrossRef]

15. Wojtkowiak, J.; Amanowicz, Ł.; Mróz, T. A new type of cooling ceiling panel with corrugated surface-Experimental investigation. Int. J. Energy Res. 2019, 43, 7275-7286. [CrossRef]

16. The Regional Inspectorate of Environmental Protection. WIOS. Available online: https://powietrze.gios.gov.pl/pjp/station/ search (accessed on 10 August 2021).

17. Siedlecki, M.; Szymlet, N.; Sokolnicka, B. Influence of the Particulate Filter Use in the Spark Ignition Engine Vehicle on the Exhaust Emission in Real Driving Emission Test. J. Ecol. Eng. 2020, 21, 120-127. [CrossRef]

18. Merkisz, J.; Gallas, D.; Siedlecki, M.; Szymlet, N.; Sokolnicka, B. Exhaust emissions of an LPG powered vehicle in real operating conditions. In Proceedings of the E3S Web of Conferences, EDP Sciences, Polanica-Zdrój, Poland, 8-10 April 2019; Volume 100, p. 00053. [CrossRef]

19. Szymlet, N.; Lijewski, P.; Sokolnicka, B.; Siedlecki, M.; Domowicz, A. Analysis of Research Method, Results and Regulations Regarding the Exhaust Emissions from Two-Wheeled Vehicles under Actual Operating Conditions. J. Ecol. Eng. 2020, 21, 128-139. [CrossRef]

20. Lijewski, P.; Kozak, M.; Fuć, P.; Rymaniak, Ł.; Ziółkowski, A. Exhaust emissions generated under actual operating conditions from a hybrid vehicle and an electric one fitted with a range extender. Transp. Res. Part D Transp. Environ. 2020, 78, 102183. [CrossRef]

21. Fuć, P.; Lijewski, P.; Siedlecki, M.; Sokolnicka, B.; Szymlet, N. Analysis of particle mass and number emission from an SI engine with direct fuel injection and a particulate filter. IOP Conf. Ser. Mater. Sci. Eng. 2018, 421, 042019. [CrossRef]

22. Rymaniak, L. Comparison of the combustion engine operating parameters and the ecological indicators of an urban bus in dynamic type approval tests and in actual operating conditions. In Proceedings of the MATEC Web of Conferences, EDP Sciences, Poznan, Poland, 27-29 June 2017; Volume 118, p. 00009.

23. Rajšić, S.F.; Tasić, M.D.; Novakovic, V.T.; Tomašević, M.N. First assessment of the PM10 and PM2.5 particulate level in the ambient air of Belgrade city. Environ. Sci. Pollut. Res. 2004, 11, 158-164. [CrossRef]

24. Pajek, L.; Košir, M.; Kristl, Ž.; Kacjan Žgajnar, K.; Dovjak, M. Indoor Environmental quality (IEQ) in Slovenian children daycare centres. Part I: Results of in-situ measurements. Int. J. Sanit. Eng. Res. 2017, 11, 4-18.

25. Mendes, A.; Aelenei, D.; Papoila, A.L.; Carreiro-Martins, P.; Aguiar, L.; Pereira, C.; Neves, P.; Azevedo, S.; Cano, M.; Proença, C.; et al. Environmental and Ventilation Assessment in Child Day Care Centers in Porto: The Envirh Project. J. Toxicol. Environ. Health Part A 2014, 77, 931-943. [CrossRef]

26. Canha, N.; Mandin, C.; Ramalho, O.; Wyart, G.; Ribéron, J.; Dassonville, C.; Hänninen, O.; Almeida, S.M.; Derbez, M. Assessment of ventilation and indoor air pollutants in nursery and elementary schools in France. Indoor Air 2016, 26, 350-365. [CrossRef]

27. Stankevica, G.; Lesinskis, A. Indoor Air Quality and Thermal Comfort Evaluation in Latvian Daycare Centers with Carbon Dioxide, Temperature and Humidity as Indicators. J. Civ. Eng. Arch. 2012, 6, 633-638. [CrossRef]

28. Jacobs, P. Improved Ventilation and Temperature Control in a Nursery. Proc. Indoor Air 2011, 1, 507-512.

29. Kozielska, B.; Mainka, A.; Żak, M.; Kaleta, D.; Mucha, W. Indoor air quality in residential buildings in Upper Silesia, Poland. Build. Environ. 2020, 177, 106914. [CrossRef]

30. Błaszczyk, E.; Rogula-Kozłowska, W.; Klejnowski, K.; Kubiesa, P.; Fulara, I.; Mielżyńska-Švach, D. Indoor air quality in urban and rural kindergartens: Short-term studies in Silesia, Poland. Air Qual. Atmos. Health 2017, 10, 1207-1220. [CrossRef] [PubMed]

31. Chang, J.; Shen, J.; Tao, J.; Li, N.; Xu, C.; Li, Y.; Liu, Z.; Wang, Q. The impact of heating season factors on eight PM2.5-bound polycyclic aromatic hydrocarbon (PAH) concentrations and cancer risk in Beijing. Sci. Total Environ. 2019, 688, 1413-1421. [CrossRef] [PubMed]

32. Ścibor, M.; Balcerzak, B.; Galbarczyk, A.; Targosz, N.; Jasienska, G. Are we safe inside? Indoor air quality in relation to outdoor concentration of PM10 and PM2.5 and to characteristics of homes. Sustain. Cities Soc. 2019, 48, 101537. [CrossRef]

33. Blocken, B.; van Druenen, T.; Ricci, A.; Kang, L.; van Hooff, T.; Qin, P.; Xia, L.; Ruiz, C.A.; Arts, J.; Diepens, J.; et al. Ventilation and air cleaning to limit aerosol particle concentrations in a gym during the COVID-19 pandemic. Build. Environ. 2021, 193, 107659. [CrossRef]

34. Hayashi, M.; Yanagi, U.; Azuma, K.; Kagi, N.; Ogata, M.; Morimoto, S.; Hayama, H.; Mori, T.; Kikuta, K.; Tanabe, S.; et al. Measures against COVID-19 concerning Summer Indoor Environment in Japan. Jpn. Arch. Rev. 2020, 3, 423-434. [CrossRef]

35. Branco, P.; Alvim-Ferraz, M.D.C.; Martins, F.; Sousa, S. Children's exposure to indoor air in urban nurseries-part I: $\mathrm{CO}_{2}$ and comfort assessment. Environ. Res. 2015, 140, 1-9. [CrossRef] 
36. Theodosiou, T.; Ordoumpozanis, K. Energy, comfort and indoor air quality in nursery and elementary school buildings in the cold climatic zone of Greece. Energy Build. 2008, 40, 2207-2214. [CrossRef]

37. Leung, D.Y.C. Outdoor-indoor air pollution in urban environment: Challenges and opportunity. Front. Environ. Sci. 2015, 2, 69. [CrossRef]

38. Tang, D.; Wang, C.; Nie, J.; Chen, R.; Niu, Q.; Kan, H.; Chen, B.; Perera, F. Health benefits of improving air quality in Taiyuan, China. Environ. Int. 2014, 73, 235-242. [CrossRef] [PubMed]

39. Li, S.; Williams, G.; Guo, Y. Health benefits from improved outdoor air quality and intervention in China. Environ. Pollut. 2016, 214, 17-25. [CrossRef]

40. Merema, B.; Delwati, M.; Sourbron, M.; Breesch, H. Demand controlled ventilation (DCV) in school and office buildings: Lessons learnt from case studies. Energy Build. 2018, 172, 349-360. [CrossRef]

41. Ratajczak, K.; Amanowicz, Ł.; Szczechowiak, E. Assessment of the air streams mixing in wall-type heat recovery units for ventilation of existing and refurbishing buildings toward low energy buildings. Energy Build. 2020, 227, 110427. [CrossRef]

42. Zender-Świercz, E. Assessment of Indoor Air Parameters in Building Equipped with Decentralised Façade Ventilation Device. Energies 2021, 14, 1176. [CrossRef]

43. Chan, W.R.; Li, X.; Singer, B.C.; Pistochini, T.; Vernon, D.; Outcault, S.; Sanguinetti, A.; Modera, M. Ventilation rates in California classrooms: Why many recent HVAC retrofits are not delivering sufficient ventilation. Build. Environ. 2020, 167, 106426. [CrossRef]

44. Gładyszewska-Fiedoruk, K. Correlations of air humidity and carbon dioxide concentration in the kindergarten. Energy Build. 2013, 62, 45-50. [CrossRef]

45. Mijakowski, M.; Sowa, J. An attempt to improve indoor environment by installing humidity-sensitive air inlets in a naturally ventilated kindergarten building. Build. Environ. 2017, 111, 180-191. [CrossRef]

46. Gładyszewska-Fiedoruk, K. Analysis of stack ventilation system effectiveness in an average kindergarten in north-eastern Poland. Energy Build. 2011, 43, 2488-2493. [CrossRef]

47. Zender-Świercz, E. A Review of Heat Recovery in Ventilation. Energies 2021, 14, 1759. [CrossRef]

48. Ratajczak, K.; Basińska, M. The Well-Being of Children in Nurseries Does Not Have to Be Expensive: The Real Costs of Maintaining Low Carbon Dioxide Concentrations in Nurseries. Energies 2021, 14, 2035. [CrossRef] 